\title{
SECRECY IN PRETRIAL DISCOVERY: HOW NON-RENDERING COURTS SHOULD TREAT PRIOR PROTECTIVE ORDERS IN SUBSEQUENT LITIGATIONS
}

By

Naphtali Ukamwa

\section{TABLE OF CONTENTS}

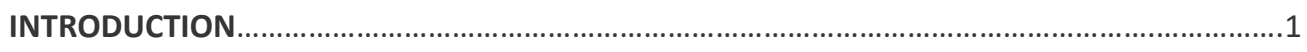

I. PRETRIAL PROTECTIVE ORDERS AND DEFERENCE...........................................................

A. The Rise of Pretrial Protective Orders and the Issuing Court's Discretion ..........................7

B. Conceptual Rifts in the Protective-Order Framework ...........................................................9

C. Protective-Order Modification ........................................................................................... 11

D. Overview of Deference in the Protective-Order Regime ..................................................12

1. Deference And Discretion .............................................................................................15

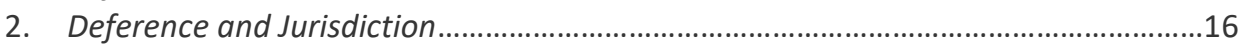

II. DEFERENCE AND PROTECTIVE-ORDER MODIFICATION.....................................................18

A. Broad Justifications for Deference to the Issuing Court....................................................18

B. Ouster Clauses in Protective Orders...................................................................................21

C. Approaches to Protective-Order Modification in Non-rendering Courts...........................23

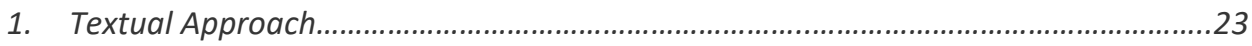

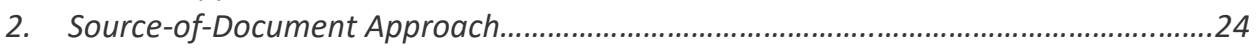

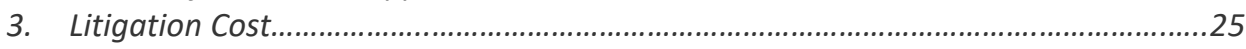

4. Variation of Existing Rights and Obligations............................................................26

5. The Doctrine of Allocation of Authority....................................................................26

III. PROPOSAL FOR PROTECTIVE-ORDERS MODIFICATION IN NON-RENDERING COURTS..........27

A. Modification-enabling Clauses Versus Subsequent Modification ........................................28

B. Protective-Order Modification Standards For Non-rendering Courts................................30

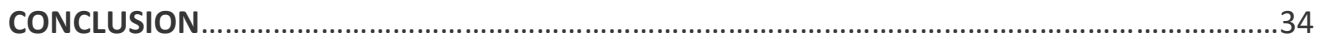

\section{INTRODUCTION}

In American civil discovery, the position is clear, or so it appears: a court other than the issuing court has no authority to modify, lift or vacate a prior protective order in subsequent litigations. ${ }^{1}$ The authority to issue and supervise protective orders is "singularly within the

\footnotetext{
${ }^{1}$ See Public Citizen v. Liggett Group, 858 F.2d 775, 780-82 (1st Cir.1988) (stating that when a federal or state court issues a protective order, it does not only "[survive] the underlying litigation", the issuing court "retains jurisdiction to and authority to modify or revoke it.). See also United Nuclear Corp. v. Cranford Ins. Co.,905 F.2d 1424, 1427 (10th Cir.1990) (noting that "as long as a protective order remains in effect, the court that entered it retains jurisdiction to modify it, even if the underlying suit has been dismissed. Modification of the order, like its initial issuance, is a matter of discretion for the court."); "Rogers v. Proctor \& Gamble Co., 107 F.R.D. 351, 352 (E.D.Mo.1985) (concluding that "every court has supervisory power over its record and files, and the decision to lift a protective order is a discretionary function for the court that issued it."); Dushkin Publ'g Group, Inc. v. Kinko's Serv. Corp., 136 F.R.D. 334, 336(D.D.C.1991) (reasoning that "a party in a lawsuit in one jurisdiction which seeks discovery covered by a protective order issued by another court has the standing to intervene in that litigation to seek a ruling, and the court that issued the protective order retains jurisdiction to decide such a motion."); See Puerto Rico Aqueduct and Sewer Auth. v. Clow Corp., 111 F.R.D. 65, 67-68 (D.P.R.1986) (concluding that "the
} 
discretion of the trial court" ${ }^{2}$ Specifically, some courts extend this principle a step further, by applying it not only to pending cases but also to dismissed and settled cases. ${ }^{3}$ This judicial practice is commendable as it is hardly deniable that parties' reliance on the weight of the protective order reinforces and makes more effective the discovery process. ${ }^{4}$ However, this practice creates two contending necessities. On the one hand, non-rendering courts dealing with the protective orders issued by another court in previously settled and currently pending litigations often have a legitimate desire to achieve "practical solutions". ${ }^{5}$ They seek to attain this objective by considering modification motions through the lenses of Rule-1 and 26 efficiency considerations, judicial economy ${ }^{6}$ and the necessity to circumvent duplicative discovery that puts an unfair burden on litigants. ${ }^{7}$ On the other hand, courts seeking to achieve these aims are often constrained by principles of comity, courtesy and, if they are federal courts, federalism. ${ }^{8}$ Thus many courts have concluded that the appropriate medium for parties and nonparties seeking to challenge a protective order is to apply to intervene in the litigation in which it was issued and comity considerations demand that the non-rendering court await the decision of the issuing court. ${ }^{9}$

No one disputes, or so it seems, the extensive nature of the discretionary power that the Federal Rules of Civil Procedure ("the Rules") confers on a trial judge to enter and supervise protective orders, ${ }^{10}$ and that it has a generic precinct of its own that may not only vary depending on the circumstances of each case but also merit protection. ${ }^{11}$ But what dangers do

proper way for a third party to challenge a protective order is to move to intervene in the action in which it was issued, and principles of comity require a subsequent court to await a ruling by the court that issued the order").

${ }^{2}$ Id.

${ }^{3}$ See Tucker v. Ohtsu Tire \& Rubber Co., Ltd., 191 F.R.D. 495, 498 (D. Md. 2000) (hereafter referred to as Tucker case") ("[T]he Order states that it " shall be considered as an Order" of the Texas state court, and " shall survive and remain in full force and effect after termination" of the Hernandez litigation.").

${ }^{4}$ An outcome the issuing court might not have achieved in a given case.

${ }^{5}$ Broyhill, 123 F.R.D. 527, 531 (W.D.N.C. 1988) ("This Court is sensitive to the values of Federalism and judicial comity, but the practical situation faced by Plaintiffs-who did, after all, try to intervene in the state court action to have the protective order modified-weighs heavily towards a practical solution")

${ }^{6}$ Tucker case, supra note3 (stating that "[i]t is difficult to imagine why the Texas court should be asked to take time from more pressing tasks to consider..... contested discovery dispute which it never considered in the case before it, and the outcome of which will be important only to the litigation in this court.").

${ }^{7}$ Id. ("to ask the plaintiffs to bear the expense of filing a new action in the Texas state court seeking a modification of the Order it issued in the Hernandez case would impose a far greater burden and expense than if this court decides the issue.").

${ }^{8}$ See Dushkin Publ'g Group supra, note 1 ("[t]his court as a matter of comity respects the order issued by the[another court"]. See also U.S. v. GAF Corp., 596 F.2d 10, 16 (2nd Cir.1979; Puerto Rico Aqueduct and Sewer Auth. v. Clow Corp., 111 F.R.D. 65, 67-68 (D.P.R.1986).

${ }^{9}$ See Deford v. Schmid Prod. Co., 120 F.R.D. 648, 650, 655(D.Md.1987) (Observing summarily that matters of comity and courtesy involved where the federal court is requested to modify a discovery order issued previously by a state court).

${ }^{10}$ See Robert C. Post, The Management of Speech: Discretion and Rights, The Supreme Court Review 1984 (1984): 169-236.

${ }^{11}$ Seattle Times Co. v. Rhinehart, 467 U.S. 20 (1984). See also Public Citizen supra, note 1, (" stating that the issuing court has "an inherent power to modify discovery-related protective orders, even after 
protective orders pose to subsequent litigations that warrant their modification and vacation? And what are the means that should be employed for their solutions? Public interest is one big concern: the concern that protection guaranteed through the confidentiality of protective orders might be used to corrode public health and safety. ${ }^{12}$ Similarly, there is the agitation that the use of protective orders poses restraint on First Amendment right. ${ }^{13}$ There is also the concern that unregulated protective orders in civil discovery process could undermine public confidence in the judicial process. ${ }^{14}$

Items obtained through protected discovery are indeed precluded from disclosure and sharing in a manner contrary to the stipulations in the order. ${ }^{15}$ Nevertheless, overzealous courts frequently enter protective orders so extensive that bind parties and nonparties in pending and subsequent litigations from access to information obtained under protected discovery. ${ }^{16}$ While the concerns for public safety is not a thing to be undermined, the privacy and proprietary interests of litigants are countervailing necessities that the court can not merely gloss over away. ${ }^{17}$ Thus, a court faced with motions to modify an initial protective order has these interests to guide the use of its discretion in allowing or refusing modification.

The antecedents of secret settlements may have given protective orders as well as the discretion of the issuing judge a bad label over the years. ${ }^{18}$ Different US jurisdictions trying to curb the so-called evils that inhere in the use of confidentiality agreements, and by extension protective orders, have had to oscillate between a regime of no regulation as well as a regime of

judgment, when circumstances justify."). Marcus, Myth and Reality in Protective Order Litigation, 69 Cornell L.Rev. 1, 41-53 (1983).

12 Owen M. Fiss, Foreword: The Forms of Justice, 93 Harv. L. Rev. 1, 2 (1979\} ("Adjudication is the social process by which judges give meaning to our public values."). See also Abram Chayes, The Role of the Judge in Public Law Litigation, 89 Harv. L. Rev. 1281, 1284 (1976).

${ }^{13}$ In re Halkin 598 F.2d 176 (D.C. Cir. 1979).

${ }^{14}$ See Owen M. Fiss, Comment, Against Settlement, 93 Yale L.J. 1073, 1076 (1984). See also David Luban, Settlements and the Erosion of the Public Realm, 83 GEO. L.J. 2619, 2621 (1995).

${ }^{15}$ See Carrie Menkel-Meadow, Whose Dispute Is It Anyway?: A Philosophical and Democratic Defense of Settlement

(In Some Cases), 83 GEO. L.J. 2663 2680, 2690 (1995); and Richard L. Marcus, supra, note 11, at 1,16, 44 (1983) (arguing that stipulated protective orders are a "form of party autonomy that is critical to the reliability of such orders").

${ }^{16}$ See Barrella v. Vill. of Freeport, 12-cv-0348 (ADS)(WDW), 3 (E.D.N.Y. Dec. 8, 2012) (The protective order expressly stipulated that "Discovery Material produced in connection with this Action shall be used solely to prosecute or defend this Action and nor for any other purpose, including, without limitation, ... any other litigations....")

${ }^{17}$ Existing literature has dealt greatly with these concerns: See Arthur R. Miller, Confidentiality, Protective Orders, and Public Access to the Courts, 105 Harv. L. Rev. 427, 464 (1991) ("Privacy can be a matter of concern to the plaintiff, the defendant, and nonparties in a wide array of lawsuits."); Seattle Times, 467 U.S. at 35 (acknowledging a "substantial interest" in avoiding risk to privacy arising from the release of discovery materials.").

${ }^{18}$ David Luban, supra, note 14, at 2648-50 (stating that "[t]he sticking point with settlements is not truth but openness. Parties consummate settlements out of public view. The facts on which they are based remain unknown, their responsiveness to third parties who they may affect is at best dubious, and the goods they created are privatized and not public. Settlements are opaque."). 
absolute proscription and limited regulation of secrecy in settlements, and by implication protective orders. ${ }^{19}$

However, courts dealing with requests to modify the protective orders issued by another court have failed to formulate a consistent legal theory - a doctrine generally applicable and need not bow to every new situation. Sadly, the Federal Rules of Civil Procedure did not spell out the guidelines that a court, other than the issuing court, should adopt when faced with a motion to modify the protective order of a prior court. ${ }^{20}$ In the absence of any express provision in the Rules, one can only expect judicial speculations on the competence of a nonissuing court to modify protective orders of another court.

The US courts have had to battle this predicament with different courts oscillating from one principle to another as justifications for and against deference to the issuing court. Indications of this inconsistency exist throughout judicial rulings on requests to modify protective orders issued by a prior court. ${ }^{21}$ For instance, some courts acknowledged that there is less need for comity and federalism where it will place an unfair burden on the party seeking modification of a protective order issued by a different court in a prior or pending litigation. ${ }^{22}$ Some courts established that stipulated protective order is no more than simple contract with inferior judicial potency and as such subsequent courts have less need for deference to the issuing court. ${ }^{23}$ Still, another court insisted that there is less need for deference and comity where the modification of a protective order of another court does not amount to a variation of the existing rights and obligations of the parties in the prior order. ${ }^{24}$ Other courts insist on deference, stating that the need for judicial comity and courtesy outweighs the avoidance of duplicative efforts. ${ }^{25}$

While protective orders were designed to curb unnecessary disclosures by litigants and their lawyers, they were not considered to pose any particular concern to parties and judges, in subsequent litigations, who must decide what weight should be given to protective orders issued by a prior court. What threats do non-rendering courts pose when they refuse to defer to the issuing court for modification or vacation of protective orders? And what are the means that should be employed for their solutions? The efficiency of the protective order is one major concern: the concern that allowing non-rendering courts to modify a protective order might

\footnotetext{
${ }^{19}$ Roscoe Pound Inst., Materials Of Secrecy Practices In The Courts: State Anti-Secrecy Measures 101-03 (2000) (setting out a comprehensive list of state statutes and rules that restrain the extent to which sealing is permissible), available at http://www.roscoepound.org/new/00mats.pdf; R. Bryan Morrison, Note, To Seal or Not to Seal? That Is Still the Question: Arkansas Best Corp. v. General Electric Capital Corp., 49 ARK. L. REV. 325, 350-51 (1996) ("A Florida court cannot enter a sealing order which conceals a public hazard or information useful to members of the public in protecting themselves from a public hazard.").

${ }^{20}$ Fed.R.Civ.P. 26.

${ }^{21}$ See cases in notes 1-7 above.

${ }^{22}$ Tucker case supra, note 3.

${ }^{23}$ LeBlanc v. Broyhill supra, note 5 and Carter-Wallace Inc. v. Hartz Mountain Indus. Inc., 92 F.R.D. 67 (S.D.N.Y.1981).

${ }^{24}$ Tucker case supra, note 3.

${ }^{25}$ See Barrella supra, note 16.
} 
corrode the continued effectiveness of protective orders and civil discovery. ${ }^{26}$ There is also a similar fear that giving the non-rendering court the latitude to modify orders of another court could undermine the future litigants' reliance on the sustained use of protective orders and the discovery process. ${ }^{27}$ Still, some have argued, without explanation, that as a matter of comity and federalism non-rendering state or federal court ought to defer to the issuing court for protective-order modification. ${ }^{28}$

Simply put, the issue that presents itself, at the heart of this Article is what weight, if any, should a non-rendering court accord the protective orders emanating from pending, settled and dismissed cases in other courts? ${ }^{29}$ This Article adds a special tone to the already loud voices on protective-order modification, arguing principally that absolute deference to the issuing court is a leeway for duplicative discovery that places an unfair burden on litigants, a consequence that diminishes sound judicial administration and the Rule-1 objectives. This Article will advance the policy argument that excessive deference to the issuing court is an invitation for absolute insulation of the party insisting on it to decline cooperation in subsequent litigations ${ }^{30}$, which has the potential for engendering further secrecy of bad products and conducts at the expense of public safety. This article will assess the justifications and criticisms underpinning the idea of deference to the issuing court to modify and vacate its orders, emphasizing the validity of those justifications and criticisms and the prospect for meaningful balance to cater for necessary practicalities and the legitimate interests of litigants while allowing subsequent parties to benefit from civil discovery in substantial ways.

PART I covers the growth of protective orders as vital devices in the civil discovery process, evaluating both the issuing court's discretion to issue and modify these orders. PART II examines the main justifications and criticisms underpinning the idea of deference to the issuing court for modification and vacation of its orders, and the prospect for meaningful balance to cater for necessary practicalities and the legitimate interests of litigants while allowing principles deference and comity to benefit civil discovery in substantial ways. PART III examines principles

26 Halkin judgment recognized the significance of protective order in promoting "the effective functioning of the civil discovery system."' Rhinehart established that "the integrity of the discovery process" could be secured as long as the trial court has the liberty to exercise "a broad discretion to manage the discovery process in a fashion that will implement the goal of full disclosure of relevant information and at the same time afford the participants protection against harmful side effects."' see also Martindell v. International Tel. Tel. Corp., 594 F.2d 291 (2d Cir. 1979)

${ }^{27}$ Id.

In Rhinehart, the Supreme Court of Washington established that without the confidence that items obtained during discovery " will be used only for the legitimate purpose of litigation" the fear of publicity might cause litigants to withhold materials, "shade the truth" or "forego the pursuit of their just claims"

${ }^{28}$ Most courts confronting this issue have merely glossed over it. See Tucker case supra, note 3, at 495,498 (suggesting that although non-rendering courts often face request for deference they have failed to give adequate attention: "there is little helpful authority to aid in its resolution, it deserves to be discussed in more detail.").

${ }^{29}$ Tucker case supra, note 3, at 495, 499 ("The issue that presents itself, then, is what weight, if any, should this court give to the order issued by the Texas state court.")

${ }^{30}$ Id."there is something unsettling about the notion that [the party insisting on deference] might forever be insulated from producing discovery in this case, or other actions, by having once produced it in a protected fashion in the [previous court and] case." 
for the treatment of protective orders in non-rendering courts. This part argues for the abolition of ouster clauses in protective others and more use of modification-enabling clauses that empower the subsequent court to modify prior order for the limited purpose of ensuring efficient discovery in related litigations. The need for deference would not have arisen had the issuing court in the exercise of its discretion at the point of entering the protective order insists on modification-friendly clauses that enable the non-rendering court to modify the former's protective order.

\section{PRETRIAL PROTECTIVE ORDERS AND DEFERENCE}

The practice of secreting pretrial discovery items from the public in general and specifically from similarly situated litigants is prevalent in American civil litigation. ${ }^{31}$ Before trial, courts and litigants' lawyers freely adopt secrecy orders to restrain access to non-parties to expedite discovery. ${ }^{32}$ Numerous litigations and settlements contracts are often crafted with extensive exclusion clauses that not only restrain access but also indefinitely extend the life of the orders to post-trial events restricting even non-rendering courts. ${ }^{33}$ These contracts and courtsanctioned orders frequently have "return or destroy" clauses that oblige the receiving party to, after settlement, return or destroy all protected items obtained through the discovery process. ${ }^{34}$ These constrain subsequent litigants and the authority of non-rendering courts to deal effectively with cases pending before them where parties in these cases are insulated by the prior protective orders of another court. Even in disputes that eventually result in trials, some courts have unaccountably put testimony and exhibits under seal. ${ }^{35}$ Thus, future litigants seeking to bring litigations in non-rendering courts will have to defer to the issuing court and await its decision to lift its seal or modify its order while the parties in the subsequent case suffer the unfair burden. ${ }^{36}$

Virtually all contours of the court-secrecy debate emanate from an underlying foundationthe indiscriminate use of protective orders. ${ }^{37}$ Secreted discovery, through protective orders,

\footnotetext{
${ }^{31}$ See, Laurie Kratky Dore, Secrecy by Consent: The Use of Limits of Confidentiality in Pursuit of Settlement, 74 Notre Dame L. Rev. 283, 285 (1999) (noting the common use of secrecy in civil litigation)

${ }^{32}$ Id. at 332 ("To expedite discovery and avoid repeated motions for a protective order regarding every document believed to be confidential, parties will frequently agree to, and courts will regularly issue umbrella protective orders.").

${ }^{33}$ See Barrella supra, note 16 and Tucker case supra, note 3.

${ }^{34}$ Joseph F. Anderson, Jr., Secrecy in the Courts: At the Tipping Point?, 53 Vill. L. Rev. 811, 814 (2008) (analyzing motions from one or both of the parties to enter protective orders having "return or destroy" clauses. See also 8A Charles Alan Wright Et Al., Federal Practice And Procedure § 2284.1 n.4 (3d ed. 2010) (analyzing the likely sources of a duty to preserve material in possession of a party).

${ }^{35}$ See Idar v. Cooper Tire \& Rubber Co., No. C-10-217, 2011 U.S.Dist. LEXIS 77568, at *4 (S.D. Tex. July 18, 2011).

${ }^{36}$ Tucker case supra, note 3 at 191 (arguing that to defer to the issuing court amounts to placing an unfair burden on it and the requesting party since the producing party has control and could easily produce the information sought.)

${ }^{37}$ Dustin B. Benham, Proportionality, Pretrial Confidentiality, and Discovery Sharing, 71 Wash. \& Lee L. Rev. 2190 (2014),
} 
occurs in numerous litigations that are eventually settled. ${ }^{38}$ This implies that secrecy in discovery is the consideration parties furnish for effective settlements. ${ }^{39}$ Consequently, it is not unexpected that early secrecy debate concentrated on the propriety and impropriety of protective orders.

The next two subparts briefly examine the American protective-order regime and specific, but vital, concerns radiating from the uses of pretrial protective orders to restrain subsequent access in other courts and cases. It will also present a doctrinal overview of deference to issuing court in the context of protective-order modification.

\section{A. The Rise of Pretrial Protective Orders and the Issuing Court's Discretion}

Since 1938, the emergence of the Federal Rules of Civil Procedure has been a crucial turning point in modern civil discovery. In what has been termed, a "striking and imaginative departure from tradition" 40 the FRCP stripped pleadings of their primordial roles as channels for specifying issues and generating information, and confer these roles on pretrial discovery process ${ }^{41}-a$ litigant-driven procedure ${ }^{42}$ that turned out to be a tremendous tool for obtaining access to materials in civil litigation. ${ }^{43}$ Considering the potentiality of deploying this development as a chariot for intimidating litigants, the FRCP saddles the trial judge with discretionary authority to rein the civil discovery process through the issuance of protective orders. ${ }^{44}$ As the Rules developed, protective orders, initially issued concerning depositions, ${ }^{45}$ were enlarged to deal with written interrogatories and requests for admission. ${ }^{46}$ Ultimately, the rules regulating protective orders were amalgamated into Rule $26(\mathrm{c})^{47}$, which conferred on judges an extensive power to issue protective orders for all kinds of discovery..$^{48}$

Upon a showing of "good cause", a party may move a court to issue a protective order to for

\footnotetext{
${ }^{38}$ See Dore supra, note 31 at 384-85 (explaining the intersection between confidentiality and settlement). ${ }^{39} \mathrm{Id}$. at 384 ("Secrecy undoubtedly facilitates the settlement process, and in some cases, compromise could not be reached without some assurance of its confidentiality.").

${ }^{40}$ Proposed amendments to the Federal Rules of Civil Procedure, Advisory Committee's Explanatory Statement concerning Amendments of the Discovery Rules, 48 F.R.D. 487 (1970).

${ }^{41}$ Hickman v. Taylor, 329 U.S. 495, 500-01 (1947).

${ }^{42}$ Advisory Committee on Civil Rules, "Topic Disc.-3, The Extrajudicial Operation of Discovery: A Tentative Approach toward Improvement" (Oct. 8, 1963), at 1.("To the extent possible, discovery should take place through procedures instituted and carried out by the parties without judicial intervention.")

${ }^{43}$ Hickman supra, note 41 at 501.

44 As the province of modern civil litigation expands with its attendant complexities, discovery misapplication flourished with alarming rapidity in the American legal system - Holtzoff, The Elimination of Surprise in Federal Practice, 7 Vand. L. Rev. 576, 580 (1954).

${ }^{45}$ See 8 A Charles Alan Wright, supra, note 34 at $\S 2035$ (3d ed. 2010) (Portraying cases that presented the historical restrictions imposed on protective orders).

${ }^{46} \mathrm{Id}$. (Explaining the effect of the 1948 amendments).

${ }^{47}$ FED. R. CIV. P. 26(c) provides that "[u]pon motion by a party or by the person from whom discovery is sought, and for good cause shown, the court in which the action is pending ...may make any order which justice requires to protect a party or person from annoyance, embarrassment, oppression, or undue burden or expense..."

${ }^{48}$ See 8 A Charles Alan Wright, supra, note 34 ("[L]anguage of the protective order section ... was changed to make it directly applicable to all forms of discovery."
} 
protection "from annoyance, embarrassment, oppression, or undue burden or expense" ${ }^{49}$ Since the power of the trial court to issue protective orders was limited only by the nebulous legal conditions of "good cause", ${ }^{50}$ it became a tool that allows judicial flexibility ${ }^{51}$ and gave the issuing court total competence over the discovery process employing the exercise of "enlightened discretion" to determine what strictures may be required for each case. ${ }^{52}$

Rhinehart v. Seattle Times $\mathrm{Co}^{53}$ established that issuance of protective orders is a matter within the precinct of "broad discretion" of the trial judge. ${ }^{54}$ From the reasoning of the Court, notwithstanding any interests that protective orders may constrain, ${ }^{55}$ the "interest of the judiciary in the integrity of its discovery processes " validates the discretionary power of the trial court to issue these orders. ${ }^{56}$ However, the Halkin court argued that the discretion of the trial court when issuing protective orders should be weighed on a scale of some requirements bordering on the First Amendment wand. ${ }^{57}$ The Rhinehart Court viewed these conditions as "unduly complex and onerous", and would inhibit "the objectives of the pretrial discovery." 58 Therefore, the issuing court's "management of pretrial discovery could be constitutionally accorded the flexibility necessary to attain its ends" ${ }^{59}$-ends which now include saving incalculable time and substantial trial costs.

As civil discovery developed and litigation turned out to be exceptionally more complex, litigants started creating agreements for umbrella protective orders that empowered the parties to treat confidential material as protected under the order. ${ }^{60}$ Since this procedure circumvents the showing of "good cause" and other requirements essential to move the court to issue a protective order, numerous litigants frequently used umbrella protective orders. ${ }^{61}$

Today, Protective orders are vital for the sound judicial administration of the discovery process $^{62}$ and this is enhanced because the issuing court has the liberty to exercise "a broad discretion to manage the discovery process in a fashion that ... implement[s] the goal of full disclosure of relevant information and at the same time afford the participants protection against harmful side effects."63

\footnotetext{
${ }^{49}$ See FED. R. Civ. P. 26(c)

50 Id.

51 Zenith Radio Corp. v. Matsushita, 529 F. Supp. at 891.

52 Wright \& Miller, Federal Practice And Procedure: Civil Procedure $\S 2036$ (1970).

5398 Wash. 2d 226, 654 P.2d 673 (1982).

${ }^{54}$ Id. 667.

55 The Halkin court stated that protective orders pose a First Amendment risk (Judge David Bazelon argued that protective orders pose "many dangers of prior restraint", and therefore necessitate "scrutiny of [their] impact on protected First Amendment expression" - In re Halkin 598 F.2d 176, 186, 191 (D.C. Cir. 1979). Halkin is considered to have curbed the flexible nature of judicial management of protective orders-See Marcus supra, note 11 at 1, 23-27 (1983).

${ }^{56}$ Post supra, note 10, at 175 citing New York Times Co. v. United States, 403 U.S. 713, 714 (1971),

${ }^{57}$ Halkin case 598 F.2d at 191-192.

${ }^{58}$ Rhinehart case 654 P.2d at 685.

${ }^{59}$ Post supra, note 10 at 178.

60 Id.

$61 \mathrm{Id}$.

62 Halkin case 598 F.2d at 192.

${ }^{63}$ Rhinehart case 654 P.2d at 689, 677.
} 
Protective orders are prevalent devices that litigants use in state and federal courts to advance several objectives. ${ }^{64}$ Parties frequently seek protective orders by Rule 26 (c) to prevent the dissemination of items gotten through the discovery process. ${ }^{65}$ Such protective orders are advantageous in several ways. They foreclose disclosure of trade secrets and other private items. ${ }^{66}$ They also have the added benefit of curbing the use of items obtained through the discovery process for non-litigation purposes.

Protective orders may be used under different situations to restrict disclosure to a specific class of persons such as the parties, the lawyers, employees and experts. ${ }^{67}$ Some strenuous orders may limit access only to experts or attorneys - restraining even the parties from access to specific items designated as confidential. ${ }^{68}$

While parties may often seek materials through discovery for other collateral aims, inherent in the notion of protective orders is the aim to advance the fundamental aim of discoverypreparation and resolution of litigation. ${ }^{69}$ For this reason, protective orders are entered to control discovered materials, even to the disadvantage of other legitimate nonparties. ${ }^{70}$

\section{B. Conceptual Rifts in the Protective-Order Framework}

Anti-secrecy advocates have pitched a long-standing thesis against protective orders. ${ }^{71}$ The strictest argument has been concentrated on public access and concerns stemming out of the friction between the debate that courts are public institutions with the primary objective of preserving social norms and the contention that when litigants bring cases to court they do surrender their privacy at the feet of the public. ${ }^{72}$ While it is strenuous to determine which side has more merits, no one doubts that pretrial secrecy, as a trait of modern litigation, fosters Rule-1 efficiency. Rule 1 provides that the Civil Rule be "construed and administered" for "

\footnotetext{
${ }^{64}$ Marcus supra, note 11.

${ }^{65}$ Zenith Radio Corp. v. Matsushita Elec. Indus. Corp., 529 F. Supp. 866, 889 (E.D. Pa. 1981\} (stating that there is no" case in the past half-dozen years of even a modicum of complexity where an umbrella protective order ... has not been agreed to by the parties and approved by the court").

${ }^{66}$ For example, the trial court by FED. R. CIV. P. 26(c)(1)(g). may enter protective order to shield litigants' "trade secret or other confidential research, development, or commercial information"

${ }^{67}$ See Dore, supra note 31 at 327 ("Courts, for example, may restrict the disclosure of such discovery to designated persons or forbid its use for purposes unrelated to the preparation and settlement of the case at hand.").

${ }^{68}$ Brown Bag Software v. Symantec Corp., 960 F.2d 1465, 1472 (9th Cir. 1992).

${ }^{69}$ Dustin B. Benham, Dirty Secrets: The First Amendment in Protective-Order Litigation, 35 Cardozo L. Rev. 1781, 1808 (2014).

${ }^{70}$ Id. at $1806-08$

${ }^{71}$ Anderson supra, note 34, at 811,813 (acknowledging that "[t]he debate over 'court-ordered' secrecy has festered for several decades").

72 Richard Zitrin, The Judicial Function: Justice Between the Parties, or a Broader Public Interest?, 32 Hofstra L. Rev. 1565, 1567 (2004) (arguing in favor of transparency because "[o]nce the disputants go to court, the public nature of the forum trumps the formerly private nature of the dispute"). Richard P. Campbell, The Protective Order in Products Liability Litigation: Safeguard or Misnomer?, 31 B.C. L. REV. $771,772-75$ (1990) (arguing in favor of privacy thesis)
} 
speedy and inexpensive determination of every action and proceeding". ${ }^{73}$

So far, the anti-secrecy advocacy has hinged on three-pronged discussions: Free-speech argument, the rule-based approach and the anti-secrecy legislation. In the latter part of the 1970s, anti-secrecy advocates advanced the Free-speech contention, which hinges on assertions that since protective orders determine how litigants use information obtained through discovery, they pose a First-Amendment restriction and therefore unconstitutional. ${ }^{74}$ Although some scholars and courts have argued that Rhinehart adequately eliminated the First Amendment thesis from the protective-order framework, ${ }^{75}$ others still believe that confidentiality order implicates free speech. ${ }^{76}$

Some scholars have cited Seattle Times as authority to establish the position that items obtained through discovery are restrained from the use by parties in related litigation. ${ }^{77}$ That argument has been rebuffed since the Seattle Times court did not pronounce on the appropriateness sharing discovery materials in other litigations. ${ }^{78}$

Anti-secrecy proponents have also argued that the Federal Rules of Civil Procedure makes provision for a right of third party access to discovery items, ${ }^{79}$ an assertion founded on the rationale that the public possessed common-law right to access the unsealed items in judicial records. ${ }^{80}$ And since the discovery was on file, the public was supposedly entitled to a claim of access to dispositions, and allied discovery-related materials. ${ }^{81}$ However, this contention has been adequately given a death blow by amendments to the rules, which now proscribes parties from filing discovery except concerning a proceeding or by a court order. ${ }^{82}$

\footnotetext{
${ }^{73}$ FED. R. CIV. P. 1.

${ }^{74}$ Benham supra note 69, at 1785-86. But see Michael Dore, Confidentiality Orders-The Proper Role of the Courts in Providing Confidential Treatment for Information Disclosed Through the Pre-Trial Discovery Process, 14 N. Eng. L. Rev. 1, 10-14 (1978) (analyzing the relationship between First Amendment and protective orders).

${ }^{75}$ See Richard L. Marcus, The Discovery Confidentiality Controversy, 1991 U. ILL. L. REV. 457, 462-63 (stating that "the broad ... prior restraint argument that captured attention in the early 1980s no longer has force.").

${ }^{76}$ See Benham supra, note 69, at 1804-14 ("The Supreme Court's opinion in Seattle Times, recent Court statements, and an assessment of the nature of both protective orders and the speech that they restrict make clear that so-called intermediate scrutiny applies").

${ }^{77}$ R. Arthurs, Defendants Fight Back on Data Sharing, Legal Times, July 16, 1984, at 1 . See also Gary L. Wilson, Note, Seattle Times: What Effect on Discovery Sharing?, 1985 Wis. L. Rev. 1055, 1056-57.

${ }^{78}$ See Marcus supra, note 75, at 495.

${ }^{79}$ See Seymour Moskowitz, Discovering Discovery: Non-Party Access to Pretrial Information in the Federal Courts 1938-2006, 78 U. Colo. L. Rev. 817, 833-853, 865-75 (2007) (contending that "the combination of Rule 5(d) filing requirement and the Rule 26 good cause provision" create a presumption of public access). ${ }^{80} \mathrm{Id}$.

${ }^{81}$ Am. Tel. \& Tel. Co. v. Grady, 594 F.2d 594, 596 (7th Cir. 1978) ("As a general proposition, pretrial discovery must take place in the public unless compelling reasons exist for denying the public access to the proceedings.").

${ }^{82}$ See Richard L. Marcus, A Modest Proposal: Recognizing (at Last) that the Federal Rules Do Not Declare that Discovery Is Presumptively Public, 81 CHI.-KENT L. REV. 331, 348 (2006) ("[A]mendments to the Rules that forbid the filing of most discovery in court . . f further, support the proposal that the notion of the Rules themselves commanding public access should be laid to rest.").
} 
'Sunshine statute' is another issue militating against protective orders. ${ }^{83}$ After several efforts at its birth room, Sunshine in Litigation Act sprouted to life in $2014 .{ }^{84}$ The statute would mandate district courts to have recourse to health and safety considerations when issuing protective orders ( by stipulation or motion) and endorsing settlements contracts. Courts would not enter protective order except a "specific and substantial interest" in preserving the secrecy of" records outweighed the public interest in disclosure of potential health or safety hazards". ${ }^{85}$

While the SILA 2014 would fundamentally aid right of public access it would also have an impact on parties in seeking to use discovery items in subsequent related litigations, and nonrendering courts would not have to defer to the issuing court, on the ground of comity and federalism, for the modification of prior protective orders. Thus, public access would mean access to parties in subsequent litigations with no need for deference to the issuing court for vacation or modification of the prior order. The Act would also affect product liability and tort cases where protective orders are often used to conceal public hazards. ${ }^{86}$

As the First-Amendment thesis remains in hibernation, the rule-based approach adequately terminated and the anti-secrecy legislation evolves, the subsequent use of items protected under discovery order tilt towards the trial court continuing discretion and supervisory function over previously issued protective orders.

The Sisyphean task arising from court secrecy has been frequently presented only as weighing between the public interest in knowing and the litigants 'right to be left alone.' The reality is that this "false binary" is a distortion to other problems that scholars have given less attention such as the fate of litigants and non-rendering courts in subsequent (related and unrelated) litigations. These groups are frequently subject to exclusion and ouster clauses in prior protective order restraining their access to discovery items in prior litigations.

The next two subparts examine the intersection between protective-order modification, issuing court's discretion and use of discovery materials in non-rendering courts.

\section{Protective-Order Modification}

Protective orders, due to their flexible nature, are subject to modification by the issuing court. ${ }^{87}$ While litigants may apply for a modification of a protective order, non-parties to the

\footnotetext{
${ }^{83}$ Roscoe Pound Inst supra, note 19. See also R. Bryan Morrison, Note, To Seal or Not to Seal? That Is Still the Question: Arkansas Best Corp. v. General Electric Capital Corp., 49 Ark. L. Rev. 325, 350-51 (1996) ("A Florida court cannot enter a sealing order which conceals a public hazard or information useful to members of the public in protecting themselves from a public hazard.").

${ }^{84}$ S. 2364, 113th Cong. (2014). See Mary Elizabeth Keaney, Note, Don't Steal My Sunshine: Deconstructing the Flawed Presumption of Privacy for Unfiled Documents Exchanged During Discovery, 62 Hastings L.J. 795, 798 (2011).

$85 \mathrm{Id}$. § 2

${ }^{86}$ See id. (proscribing protective orders in litigations "in which the pleadings state facts that are relevant to the protection of public health or safety").

${ }^{87}$ See 8 Charles A. Wright Et Al., Federal Practice And Procedure $\S 2044.1$ (2d ed. 1994\}. See Seattle Times supra, note 11 . The power to issue protective order is "singularly within the discretion of the trial court" and modifiable "only on a clear showing of abuse of discretion"
} 
actual case where the order was issued contest such orders ${ }^{88}$ by motion to modify, lift or even vacate the order. A class of third-party interested in protected discovery is the similarly situated litigants in the original litigation. This class of third parties, such as plaintiffs claiming against the same defendants could have embarked on independent discovery to obtain items covered by a protective order. They decide, in avoidance of duplicative-discovery efforts, to seek access to protected items discovered by parties in prior litigation.

Also, non-party litigants such as public interest groups ${ }^{89}$ or media entities ${ }^{90}$ frequently contest protective orders on the justification that discovery items covered by the order implicate issues of public concern that should not be secreted. ${ }^{91}$ For instance, information concerning unsafe products in the market or actions of government officers are frequent issues of public concern justifying modification to allow nonparties access to discovery items. ${ }^{92}$

\section{Overview of Deference in the Protective-Order Regime}

Drawing on the lingo proposed by Daly ${ }^{93}$ and Foley ${ }^{94}$ this subpart provides two general grounds for deference: epistemic rationale and doctrinal rationale. ${ }^{95}$ Practically, the most accepted method of describing deference is to portray it as the attribution of weight. ${ }^{96}$ The deference thesis concerns the weight which non-rendering courts should accord the decisions or

\footnotetext{
${ }^{88}$ Generally non-parties commonly use the mechanism of intervention provided under Rule 24 (b) to request access to protected discovery items. See Id 8 ("Although requests for modification do frequently come from the litigants themselves, it is often true that they come from, or are made on behalf of, other persons."). See $8 \mathrm{id}$. ("There is a considerable body of law affirming the propriety of such limited intervention.").

${ }^{89}$ Public Citizen supra, note 1 ("prohibiting a public interest group from gaining access to protected discovered material from litigation in which it was not a party").

${ }^{90}$ Seattle Times supra, note 11 at 20 ("prohibiting a newspaper from disseminating protected material discovered in a suit in which it was a defendant").

${ }^{91}$ Abram Chayes, The Role of the Judge in Public Law Litigation, 89 Harv. L. Rev. 1281, 1284 (1976\}; see also Fiss supra, note 12, at 1, 2 (1979) ("Adjudication is the social process by which judges give meaning to our public values.").

${ }^{92}$ See Committee on Rules of Practice and Procedure, Judicial Conference of U.S., Proposed Rules 56 (Ocr. 1993) [Hereinafter Proposed Rules), reprinted at 150 F.R.D. 323, 388 (1993\} ("Information about the conduct of government officials is frequently used to illustrate an area of public concern. The most commonly offered example focuses on information about dangerous products or situations that have caused injury and may continue to cause injury until the information is widely disseminated."). See generally Brad N. Friedman, Note, Mass Products Liability Litigation: A Proposal for Dissemination of Discovered Material Covered by a Protective Order, 60 N.Y.U. L. REv. 1137 (1985) (emphasizing that secreting discovery information might result in future hazard from defective products).

${ }^{93}$ Paul Daly, Defining Deference (November 27, 2012). A Theory of Deference in Administrative Law: Basis, Application and Scope (Cambridge University Press, 2012). Available at SSRN: https://ssrn.com/abstract=2181418.

${ }^{94}$ See generally Brian Foley, Deference and the Presumption of Constitutionality (Dublin: Institute of Public Administration, 2008).

${ }^{95}$ See Gary Lawson \& Christoper D. Moore, The Executive Power of Constitutional Interpretation, 81 lowa L. REV. 1267, 1278-79 (1996).

${ }^{96}$ Daly supra, note 93.
} 
orders of the issuing court. ${ }^{97}$ Then the question is why should a subsequent court give weight to the decision of an issuing court? In an epistemic sense, ${ }^{98}$ knowledge is a vital condition for deference: A non-rendering court may find that there is a need for deference where the issuing court has more knowledge on the issues and facts surrounding the initial protective order. ${ }^{99}$

Deference also suggests the allocation of authority ${ }^{100}$ - the scope of authority that precludes an institution from going beyond firmly delineated boundaries. ${ }^{101}$ Thus, instead of giving respect to the order or decisions of another entity, one entity might allocate authority to another to make enforceable orders or decisions. ${ }^{102}$ In this sense, the assigned authority does not need to be absolute; its exercise might be restricted to certain exceptions or principles. ${ }^{103}$ In the latter sense, deference is doctrinal.

Courts have declined jurisdiction to modify protective orders of a rendering court, and where they insist that they have jurisdiction, they would as consideration of comity refuse to modify such orders. ${ }^{104}$ Thus, when a court is faced with litigation that would result in fundamental interferences or usurpation of the continuing authority of the issuing court to administer and modify its orders, comity considerations and organized judicial administration require that the non-rendering court should renounce jurisdiction and defer the case to the rendering court provided there is a remedy there. ${ }^{105}$ Many courts have concluded that the appropriate medium for parties and nonparties seeking to contest a protective order is to apply to intervene in litigation in which it was issued and comity considerations demand that the nonrendering court await the decision of the issuing court. ${ }^{106}$

\footnotetext{
${ }^{97}$ This an epistemic kind of deference. Brian Foley supra, note 94 at 256. ("Reduced to its most basic form, the deference question concerns the weight which courts should attribute to the decisions of ... institutions."). See also Murray Hunt, 'Sovereignty's Blight', in Nicholas Bamforth and Peter Leyland (eds.), Public Law in a Multi-Layered Constitution (Oxford: Hart, 2003), p. 337, pp. 346-34(Stating that deference means "when the court gives some weight to a decision of a primary decision-maker for an articulated reason, as part of its overall review of the justifications for the decision.")

98 Paul Horwitz, Three Facts of Deference, 83 Notre Dame L. Rev. 1085-1089 (2008).

${ }_{99}^{9}$ Id at 1085 (stating that "courts defer to another institution when they believe that those institutions know more than the courts do about some set of issues, such that it makes sense to allow the views of the knowledgeable authority to substitute for the courts' judgment.") citing Guy-Uriel E. Charles, Colored Speech: Cross-Burnings, Epistemics, and the Triumph of the Crits?, 93 GEO. LJ. 575, 610 (2005).

${ }^{100}$ See Daly supra note 93.

${ }^{101}$ Murray Hunt supra, note 97 at 346-347.

102 Id.

${ }^{103}$ Daly supra, note 93 at 1-2 (stating that "such authority need not be absolute: its exercise might be subject to limitations...".

${ }^{104}$ Doe v. Doe, 608 F. Supp. 2d 68, 71 (D.D.C. 2009).

${ }^{105}$ Tucker supra note 3.

106 Puerto Rico Aqueduct and Sewer Auth. v. Clow Corp., 111 F.R.D. 65, 67-68 (D.P.R.1986) Donovan v. Lewnowski, 221 F.R.D. 587, 588-89 (S.D. Fla. 2004) ("Principles of comity and respect for the effect of preexisting judicial orders") Tucker supra, note 3 (D.Md.2000) (citing Puerto Rico Aqueduct and Sewer Auth. v. Clow Corp., 111 F.R.D. 65, 67-68 (D.P.R.1986) (concluding that "the proper way for a third party to challenge a protective order is to move to intervene in the action in which it was issued, and principles of comity require a subsequent court to await a ruling by the court that issued the order"); Flavorland Indus., Inc. v. United States, 591 F.2d 524, 525 (9th Cir.1979) ("issue an order which would have the effect of contravening any purpose of [the state judge] in preserving the orderly process of private litigation ...
} 
Ohio Willow Wood Company V. Alps South LLC ${ }^{107}$ illuminates the discussion on doctrinal and epistemic deference in the context of protective-order modification. OWW got the "Chen Documents" through discovery in a lawsuit in Florida between OWW and the defendant, ALPS South LLC. The Florida court issued a protective order under which OWW obtained these documents. ${ }^{108}$ OWW did not contest the order in Florida district court, instead initiated a motion in the Ohio Court to modify the protective order to permit OWW to disclose those documents to the Patent Office in a re-examination proceeding. The Magistrate Judge refused OWW's modification request establishing that "even if the power to do so exists, it would not have been appropriately exercised here." OWW invited the District Judge to reconsider the order.

In ruling that ${ }^{109}$ the issuing court is the proper court to modify protective order issued in pending litigation, District Judge Edmund Sargus Jr, implicitly adopted doctrinal deference and epistemic deference. First, Edmund Sargus Jr asserted that an issuing court is an appropriate authority, by case law ${ }^{110}$ to modify its protective order. This is a pattern of doctrinal deference: the civil rules allocate authority to the issuing court to issue protective orders and modify them where necessary. Nevertheless, it was not an absolute authority: any protective order of the issuing court would have to fall within the exceptions that courts have carved to justify modification by the non-rendering court. ${ }^{111}$ And since the instant request does not fall into that exception, there is a need for deference to the issuing court.

Next, Edmund Sargus Jr accorded weight to the protective order of the issuing court which designated the "Chen Documents" as "Confidential - for trial counsel only". The court considered the protective order of the issuing court and while it noted that the order was meant to protect the "Chen Documents", refused to modify the order to grant access to a third party. The court did not make an independent decision; it relied fully on having given weight to the order and discovered that the order must be accorded weight.

Conversely, a court's decision not to defer to the issuing court can also be based on doctrinal and epistemic justifications. Thus, in Tucker, the court found less need for deference because the case under which the protective order was issued had been settled: although the issuing court possesses authority over its protective order, in this context, deference to that court would be a waste of its limited time and resources. Also, the Tucker court accorded weight to the protective order of the issuing court: by perusing the stipulated protective order and came up with the decision that it was a mere private contract, having lesser weight because it was "an agreement by counsel approved, almost as a ministerial act, by the court" and was

pending before him" ); Dart Indus., Inc. v. Liquid Nitrogen Processing Corp. of California, 50 F.R.D. 286, 291-92 (D.Del.1970) ("in the interest of comity, limiting production and inspection of documents to be produced in this action to those not covered by any protective order of the [issuing] court in a prior lawsuit.").

107 Ohio Willow Wood Company V. Alps South, LLC, Case No. 2:05-cV-1039 (S.D. Ohio Mar. 18, 2011).

108 Id. The documents were labelled "Confidential - for trial counsel only".

109 Citing Mugworld, Inc. v. G. March Associates, Inc., 2007 WL 2229568, *1 (E.D. Tex. June 15, 2007)

${ }^{110}$ OWW v. Alps supra, note 107 (stating that "courts have held that any request necessitating the modification of the protective order be directed to the issuing court") citation omitted (emphasis added)

111 Id. (Stating "some courts have carved out exceptions to this general rule when exceptional circumstances exist."). 
not an order of the issuing court entered "after a full consideration of the merits of [the]... dispute."112 In other words, the court did not make an independent decision; it relied partially on having given weight to the order but discovered that the order lacks sufficient weight to outweigh the need for practical solutions that Rule-26 efficiency.

\section{Deference And Discretion}

According to Horwitz, choice is a fundamental element of discretion, which is, in turn, a vital component of deference-theorizing that when courts are faced with a variety of options, their choice to defer or refusal to defer is an exercise of discretion. ${ }^{113}$ Thus, a subsequent court dealing with the protective order of another court has the discretion to defer or refuse deference. ${ }^{114}$ In other words, deference is not a rule of law cast in stones, it a principle of comity and courtesy and when the subsequent court invited to rule on a motion that modifies another court's order has the discretion to defer or decline deference.

Also, assuming that several other solutions are available to a subsequent court, which, if it chooses to defer, the issuing court will still attain the same solutions, then its decision not to defer is justified as an exercise of discretion. ${ }^{115}$ Similarly, if ranges of conclusions are probable if a subsequent court decides not to defer to the issuing court, then its decision not to defer is an exercise of discretion. ${ }^{116}$ For example, where a court is invited to modify the order of another court in a previously settled case, the modifying court may decide not to defer to the issuing court, where it has the option of choosing between two contending interests such the confidential interest of the producing party and the unfair burden on the requesting party, the choice to refuse deference and modify the order in favour of one of these interests is a discretion. Also, when a non-rendering court is invited to modify a protective order of another court issued in a pending or settled case establishes that deference outweighs the need to avoid duplicative discovery efforts; it is an exercise of courts discretion. Therefore, "while the decision to defer is itself an exercise of discretion, deference is ultimately only a subset of the larger field of discretion."

\footnotetext{
112 Tucker case supra, note 3.

${ }^{113}$ Paul Horwitz, supra note 98 at 1077 (stating that "an important aspect of deference is D1's choice, when confronted with a range of options, to displace its judgment with the judgment of D2. That choice is an exercise of discretion. But a court that declined to defer to the judgment of another institution, and instead rested on its independent judgment, would also be exercising its discretion in selecting that option.").

${ }^{114}$ Generally, all court trial courts have broad discretion over issues dealing with the protective order. The Rules have no distinction between the issuing and non-rendering court-all are trial courts. See FED. R. CIV. P. 26.

${ }^{115}$ For example, a court may not defer if its modification does not alter the obligations and rights of the parties under the order of the other court. Also, where an initial protective order violates the First Amendment Right, a subsequent court may modify such other where it is clear that the issuing court will still arrive at the same conclusion. The principle of judicial and administrative economy justifies this position. See Tucker case supra note 3.

${ }^{116}$ See Paul Horwitz supra, note 98 at 1077 ( stating that where "a variety of conclusions are possible if a court does exercise independent judgment-if, say, some equally plausible readings of a statute are available to it-then its decision to adopt one conclusion over another will be an exercise of discretion.").
} 
The fact that courts have a consensus that deference is a constraining policy for a subsequent court invited to modify the order of another court does not translate to a diminution of the discretion of the deferring court. ${ }^{117}$ However, the fact that deferring courts have other options and may decide whether or not to defer establishes that deference to the issuing court is a discretionary matter. ${ }^{118}$ As a result, whether a subsequent court will find the need for deference to a prior court is a question of judicial discretion, which is likely to vary among courts except, there is a coincidence in the weight they attach to a given discretionary value (such as the preservation of the issuing court's authority). It is in this regards that the emergence of some conventional guidelines, aided by the principles of federalism, comity and courtesy, may influence different courts to adopt the same conceptual standard in dealing with prior protective orders. In instances where courts adopt different guidelines, may well be that in case of $X$ the approach adopted in addressing prior protective order is governed by some reference to rule-based interest, while case $Y$ does not. ${ }^{119}$

\section{Deference and Jurisdiction}

Commentators have argued that deference, in the general sense, amounts to the disclaimer of the deferor's jurisdiction over the matter before it. ${ }^{120}$ More precisely jurisdiction is not coterminous with deference. ${ }^{121}$ Subsequent courts that defer to the order of the issuing court, properly so-called, have not disclaimed their jurisdiction over the case pending before them, instead, they simply seek to establish that by principles of comity and courtesy, or federalism, they do not desire or it is not appropriate to modify the protective order of another court. ${ }^{122}$ This point has at least two justifications.

First, deference is a matter of discretion and choice based on peculiar circumstances: the subsequent court decides to defer to the issuing court because upon its consideration of other options, deference is the best thing to do. ${ }^{123}$ Second, deference indicates that the subsequent court has some ongoing power over the litigation before it; only issues that touch on the protective order issued by another court is deferred, it did not defer its actual authority to decide litigation before it. ${ }^{124}$ The deferring court may order the party requesting production of the prior protected discovery items to embark on his discovery, albeit duplicative discovery. ${ }^{125}$

\footnotetext{
117 Id. at 1077.

118 Id.

${ }^{119}$ For instances in Tucker case supra, note 3, at 495, 500 (D. Md. 2000) (the court distinguished its decision from precedents by stating that "all of the cases ... which discuss this issue were written before the 1993 changes to the Federal Rules of Civil Procedure.")

${ }^{120}$ See C. Thomas Dienes, When the First Amendment Is Not Preferred: The Military and Other "Special Contexts, 56 U. CIN. L. Rev. 779, 819-20 (1988) (Stating that Court's deference to another [court] is "de facto non-justiciability"). See also Paul Horwitz, Universities as First Amendment Institutions: Some Easy Answers and Hard Questions, 54 UCLA L. REV. 1497 at 1516-23 (2007).

121 Paul Horwitz supra, note 98 at 1077.

122 See notes 1-7.

123 Paul Horwitz, supra note 98 at 1077.

${ }^{124}$ Mann Manufacturing, Inc. v. Hortex, Infra note 127

125 Barrella supra, note 16 (holding that "Barrella can and should conduct his discovery.").
} 
When the subsequent court defers to the issuing court's order in a particular circumstance, it does not prevent it from make decisions on its proceedings that bind the parties. ${ }^{126}$

This position was illustrated in Mann Manufacturing, Inc. v. Hortex, Inc. ${ }^{127}$ In November 1968, Goodrich initiated a case against Mann in the Southern District Court of New York seeking a declaration that in promoting its Fabrilock program, Goodrich did not in any way infringe '405 patent' issued to Mann. Almost simultaneously, Mann initiated an action for infringement against Goodrich and Hortex (a user of Goodrich's products) in the Western District Court in Texas. Mann sought an order from the New York Court to transfer and consolidate the case with the one in Texas o ground of convenience of the forum, the New York court declined. On the permission of the New York court, Goodrich enjoined the Texas litigation.

Mann subsequently obtained ' 821 patent' in March 1970 and filed a complaint in the Texas court against Goodrich and Hortex for infringement on patent ' 821 patent on identical grounds with its earlier action on ' 405 patent in the same court.

The Texas court to "preserve its jurisdiction" issued an interim restraining order prohibiting Goodrich and Hortex from bringing on their motion relating to '821 patent' in New York provided that once it has been determined by either the discovery in New York or Texas that both suits should be consolidated the Texas court would transfer the matter to the New York court. Hence, the court ordered that discovery should continue in the two jurisdictions. On these grounds, Goodrich appealed.

The court of appeal held that considering the merit and identical nature of the case, the Texas court interfered with the order of the New York court prohibiting further litigation. Even if the matters are identical, it "does not necessarily compel" consolidation since "dominant issues might ultimately turn out to be distinct in each suit". However, because of the first-to-file rule ${ }^{128}$ the court with "prior jurisdiction over the common subject matter" retains authority to resolve all matters in related suits. ${ }^{129}$

Because the case on ' 821 patent was initially initiated in Texas, the court was justified to have ordered an interim restraint against Goodrich to prevent it from moving a motion in New York which, if granted, would have deprived the Texas court of its jurisdiction in the matter before it could hear and determine the issues.

However, the Texas court was faced with the crucial issue - the New York court's prior order restraining Mann from suing Goodrich and Hortex concerning '405 patent in Texas. The continuing nature of the Texas restraining order interfered with the New York prior order. Hence, the court argued that "[i]t is well settled that the issuing court has continuing power to supervise and modify its injunctions by virtue of changed conditions."). When "sound judicial

\footnotetext{
${ }^{126} \mathrm{Id}$.

${ }^{127}$ Mann Manufacturing, Inc. v. Hortex, Inc., 439 F.2d 403 (5th Cir. 1971).

${ }^{128}$ Bank of Am. v. Berringer Harvard Lake Tahoe, Civil Action No. 3:13-CV-0585-G (N.D. Tex. June 12, 2013).

${ }^{129}$ The court stated the underpinning principles: "[i]n the absence of compelling circumstances the court initially seized of a controversy should be the one to decide whether it will try the case." See also Rickey Land Cattle Co. v. Miller Lux, 218 U.S. 258, 31 S.Ct. 11, 54 L.Ed. 1032(1910); In re Georgia Power Co., 89 F.2d 218 (5th Cir. 1937); Tivoli Realty v. Interstate Circuit, 167 F.2d 155 (5th Cir. 1948).
} 
discretion" instigates the need to modify an order arises, whether as of fact or law, the issuing court retains the power to do so.

The validity of the issuing court's authority to modify is based on the fact that a protective order is continuing in nature. ${ }^{130}$ When a court is faced with a case that would make it interlope or usurp this continuing authority, "considerations of comity and orderly administration of justice demand that the non-rendering court should decline jurisdiction and remand the parties for their relief to the rendering court, so long as it is apparent that a remedy is available there." 131

\section{DEFERENCE AND PROTECTIVE-ORDER MODIFICATION}

The continuing authority of the issuing court over its protective orders has been justified on several grounds. ${ }^{132}$ Nonetheless, these justifications are not essentially immutable, nor do they capture the full image and the latent disadvantages that absolute deference to the issuing court will cause to civil litigation. ${ }^{133}$ The next two subparts will examine the main justifications and criticisms underpinning the idea of deference to the issuing court for modification and vacation of its orders, and the prospect for meaningful balance to cater for necessary practicalities and the legitimate interests of litigants while allowing principles deference and comity to benefit civil discovery in substantial ways.

\section{A. Broad Justifications for Deference to the Issuing Court}

The continuing efficiency of protective orders is one justification for deference to the issuing court. This reasoning finds footing in the argument that allowing non-issuing courts to modify prior protective orders might corrode the continued efficiency of protective orders in civil litigation. ${ }^{134}$ Martindell seems to suggest that non-deference to the issuing court for the enforceability of its protective orders has the potential for "undermining a procedural system that has been successfully developed over the years." ${ }^{135}$ Medina, Circuit Judge (concurring in result) stated that "[a] plaintiff in civil litigation is bound by the terms of an agreement he has

\footnotetext{
${ }^{130}$ Federation No. 91, Railway Emp. Dept., A.F.L.-C.I.O. v. Wright:364 U.S. 642, 647, 81 S.Ct. 368, 371, 5 L.Ed.2d 349(1961) (stating that protective order "requires continuing supervision by the issuing court and always a continuing willingness to apply its powers and processes on behalf of the party who obtained that equitable relief.")

${ }^{131}$ Mann supra, note 127 citing Lapin v. Shulton, Inc., 333 F.2d 169, 172 (9th Cir. 1964), cert. denied 379 U.S. 904, 85 S.Ct. 193, 13 L.Ed.2d 177 (1964).

132 Id.

${ }^{133}$ Tucker case supra, note 3. ("These principles, while unquestionably important, are not absolute," courts may not apply them in deserving circumstances.).

${ }^{134}$ Halkin judgement recognized the significance of protective order in promoting "the effective functioning of the civil discovery system."' Rhinehart established that "the integrity of the discovery process" could be secured as long as the trial court has the liberty to exercise "a broad discretion to manage the discovery process in a fashion that will implement the goal of full disclosure of relevant information and at the same time afford the participants protection against harmful side effects."'

${ }^{135}$ Martindell supra note 26, at 295.
} 
made to restrict the access of non-parties, including the Government, to the products of discovery. "136

There is also the fear that giving non-rendering courts the unrestrained latitude to modify protective orders of another court could undermine the litigant's reliance ${ }^{137}$ on these orders. ${ }^{138}$ Therefore, there is a strong presumption against access to confidential items where there is reasonable reliance on an initially granted protective order. ${ }^{139}$ There is no merit in a nonrendering courts' modification of protective orders where parties "intend to furnish discovery" in a case "in reliance upon" 140 the protective order. The element of reliance creates more need for deference and heavier burden on the party seeking modification than it might have ordinarily required ${ }^{141}$ especially where it would have been "difficult, if not impossible, to engage in meaningful discovery or settlement... without the long-enduring protection" guaranteed by the protective order. ${ }^{142}$ The burden is even heavier where the party seeking modification in the non-rendering court is the government ${ }^{143}$ because of the presumption that it possesses "special investigatory powers", ${ }^{144}$ which private litigants lack. ${ }^{145}$ However, while confidentiality of

\footnotetext{
${ }^{136} \mathrm{Id}$.

${ }^{137}$ Palmieri v. State of N.Y, 779 F.2d 861, 865 (2d Cir. 1985) ("[t]he very ... information that the Attorney General seeks apparently would not even have existed but for the sealing orders and the magistrate's personal assurances of confidentiality, upon which the appellants relied in agreeing to enter closed-door settlement negotiations. ").

${ }^{138}$ Id. 861, 862 (2d Cir. 1985) (holding that "absent an express finding by the district court of improvidence in the magistrate's initial grant of the protective orders or extraordinary circumstances or compelling need by the State for the information protected thereunder, it was error for the district court to modify the magistrate's orders.").

See Martindell supra note 26, at 291, 294 (holding that "absent a showing of improvidence in the grant of Rule 26(c) protective order or some extraordinary circumstance or compelling need . . . a witness should be entitled to rely upon the enforceability of a protective order against any third parties, including the Government, and that such an order should not be vacated or modified..." see also Zenith Radio Corp. v. Matsushita Electric Industrial Co., 1978-1 Trade Cases (CCH) 62,019 (E.D.Pa. 1978); GAF Corp. v. Eastman Kodak Co., 415 F.Supp. 129 (S.D.N.Y. 1976); In Rhinehart, the Supreme Court of Washington established that without the confidence that items obtained during discovery " will be used only for the legitimate purpose of litigation" the fear of publicity might cause litigants to withhold materials, "shade the truth" or "forego the pursuit of their just claims".

139 Martindell supra note 26.

${ }^{140}$ Palmieri supra, note 137 , at 861,863 (2d Cir. 1985) this rule is subject to the principle that nothing indicates illegality in the settlement terms.

${ }^{141}$ Id. at 861, 864-65 (2d Cir. 1985) ("reliance on Magistrate Tyler's sealing orders, though not fatal to the state's case, renders its burden heavier than it might otherwise be.").

${ }^{142}$ Id. See also Barrella supra note 16.

${ }^{143}$ See Martindell supra note 26.

${ }^{144}$ Such as "the power to subpoena persons and documents before the grand jury" Palmieri supra note 137 (stating that "[s]uch powers, of course, do not foreclose the possibility that the State may have no reasonable alternative to the method of investigation that it seeks to employ here, but they do raise a rebuttable presumption against modification of the orders."

${ }^{145}$ Wilk v. American Medical Association,635 F.2d 1295, 1299-1300 (7th Cir. 1981) (Judge John Minor Wisdom established that what was fundamental to Martindell and GAF was the consideration that "the party seeking access ... . was the federal government, which in each case had at its disposal special investigatory powers not available to private litigants....")
} 
settlement terms is a deep-rooted in American civil trial tradition, ${ }^{146}$ and whereas the degree to which judicial proceedings ought to be subject to public access may frequently be an issue "best left to the sound discretion of the trial court," 147 no volume of judicial assurance and parties' reliance thereon could validate an absolute adherence to an order improvidently issued or approved. ${ }^{148}$

Where protective orders are not ambiguous and the parties themselves concede, the issuing judges have preserved jurisdiction to administer and modify their orders. ${ }^{149}$ Thus, non-rendering court seeking to modify stipulated protective orders have often had recourse to the terms of the prior order, stating that the jurisdiction, purpose and procedures provided in the order are binding on the parties and precludes non-rendering court's authority to modify such orders. ${ }^{150}$ As a result, numerous stipulated protective orders are crafted to make provisions for terms and procedures that cover the pretrial, trial and post-trial (incorporating appellate) issues. ${ }^{151}$ While the underlying litigation in the issuing court has terminated by dismissal or settlement, the court still retains jurisdiction because "the life of the sealing and protective order" persists. ${ }^{152}$

Equally, it has been argued that the deference to the issuing court is on the basis that it is conversant with the issues in the case and has considered the potential abuse of the discovery process before issuing the order. ${ }^{153}$ Since the issuing court is more conversant with the underlying case and the nature of the protective order, it is placed in a better position to make an independent "good cause" finding and thus decide whether or not to modify the order to give access rights to nonparties in subsequent litigation. ${ }^{154}$

Also, the principle of "the law of the case" closes the discretion of the transferee court to relitigate the issue. Thus, the non-rendering court is expected to exercise its discretion to abstain from unsettling the decision of the transferor court as a matter of judicial comity. ${ }^{155}$

${ }^{146}$ In re Franklin Nat'I Bank Securities Litigation,92 F.R.D. 468, 472 (E.D.N.Y. 1981), aff'd sub nom. Federal Deposit Ins. Corp. v. Ernst Ernst,677 F.2d 230 (2d Cir. 1982.

147 Nixon v. Warner Communications, Inc., 435 U.S. 589, 599, 98 S.Ct. 1306, 1312, 55 L.Ed.2d 570 (1978),

148 Palmieri supra, note 137 at 861, 866 (2d Cir. 1985).

${ }^{149}$ Doe v. Doe, 608 F. Supp. 2d 68, 71 (D.D.C. 2009)

${ }^{150}$ Id.

${ }^{151}$ Id. For instance, the district courts stipulated orders that were the subject of interpretation provided that "[t]he procedures set forth in this Protective Order are intended to govern the time throughout all trial and post-trial (including appellate) matters in this case, and may be modified by the further order of the Court acting under its inherent supervisory authority."

${ }^{152}$ Doe supra, note 149 at 68, 71 ("While Ms Doe's case in the other jurisdiction has ended, the life of the sealing and protective orders of the courts in that jurisdiction was intended to extend past those courts' judgments.)

${ }^{153}$ Holland v. Summit Technology, Inc., Civil Action No. 00-2313 Section "C" (3), (E.D. La. Sep. 21, 2001) ("Indeed, the MDL judge may be better equipped to gauge how modifying the MDL protective order would impact the Defendant's confidentiality interests in that case.")

${ }^{154}$ Id.

155 Philadelphia Housing Authority v. American Radiator and Standard Sanitary Corp., 323 F. Supp. 381, 383 (E.D.Pa. 1970) ("The rule of the law of the case is a rule of practice, based upon the sound policy that when an issue is once litigated and decided, that should be the end of the matter. . . This principle is particularly applicable to multidistrict litigation in which the presence of a large number of diverse parties might otherwise result in constant relitigation of the same legal issue."). 


\section{B. Ouster Clauses in Protective Orders}

In product liability cases there often occurs instances where protective orders preclude subsequent use and sharing of discovery items in other litigations unless with permission of the issuing court. Provisions of this nature tie the arms of the non-rendering court to do justice to the litigation pending before them. Protective orders of this nature have practical consequences on non-rendering courts and the general system of civil litigation. By not incorporating modification-enabling provision, issuing courts deprive parties in related litigation of using discovery materials for the preparation of the subsequent litigation.

Protective orders entered with no modification-enabling clauses corrode the objective of Rule 1 in the non-rendering court's administration of its matter because they touch on an order of another court. ${ }^{156}$ The Rules do not equip one trial court with discretionary power to clog the wheels of another trial court. By restraining similar litigants and other parties from the use of discovery items other than in the instant litigation, issuing courts not only expressly and implicitly bar subsequent litigants from access to that information, they clog the wheel of smooth and efficient trials in non-rendering courts. One can only imagine the unjust hardship that parties will experience when a separate case in a non-rendering court has to be temporarily suspended because a party insists not to producing certain information covered by prior order of another court and the non-rendering court must have to defer to the issuing court to modify its order. ${ }^{157}$ Such an interpretation of deference is misleading.

Enabling protective-order modification in non-rendering court is not for the sole benefit of the requesting, it aid non-rendering courts to modify such orders in subsequent ligation, thereby creating efficiency incentives for the producing party in subsequent litigations. ${ }^{158}$ What this implies is that the producing party could simply provide discovery from prior litigations for use in subsequent cases without having to reinvent the discovery wheel and this will expedite the processes in subsequent litigations. ${ }^{159}$ This approach is substantially useful for corporate defendants that face product liability actions with overlapping facts and claims that their products are defective and have caused harm.

However, defendants that intend to conceal misconducts often insist on secrecy and the need for deference to the issuing court because of the enormous power they wield in pretrial

\footnotetext{
${ }^{156}$ Fed. R. Civ. P. 1 provides that the Rules be "administered, and employed by the court and the parties to secure the just, speedy, and inexpensive determination of every action and proceeding".

${ }^{157}$ See Tucker case supra note 3.

${ }^{158}$ Garcia v. Peeples may justify this argument because the consequences of enabling modification are similar to the outcomes of discovery sharing. See Garcia v. Peeples 734 S.W.2d 343, 346-47 (Tex. 1987) (recognizing that permitting information sharing between similarly situated litigants would boost disclosure and efficiency in the trial system).

${ }^{159}$ Carter-Wallace supra note 23.
} 
settlements ${ }^{160}$. Big companies often insist on stipulated protective orders that diminish discovery sharing and encourage deference to issuing courts because of the advantage they derive from duplicative discovery. ${ }^{161}$

By insisting on deference to the issuing court to modify a prior discovery order, defendants buy time for themselves and increase the time and expense for rediscovery or bring actions against them in the issuing court. ${ }^{162}$ It also has the implications of diminishing collaborative actions and efficiency of attorneys among subsequent litigants who could have exploited the benefit of common discovery to expose defendants that indulge in the production of defective products injurious to public health or for conducts that violate human rights for years. ${ }^{163}$

Imagine that in a hypothetical case of Obaham v. Wakanda Co., where Obaham, who suffered injury from use of Wakanda defective products, has now sued Wakanda Co. for product liability. Obaham would not be able to take advantage of protected discovery materials in previous product-liability litigations or settlements involving Wakanda Co. under strict nondisclosure orders. The Obaham's lawyer would have to invest time and resources on moving previous issuing courts to lift or modify their orders to allow him access to protected discovery items. If these issuing courts decline ${ }^{164}$ then he returns to the non-rendering court, where his case is pending and embarks on 'a voyage of re-discovery.' 165

Meanwhile the attorneys of Wakanda co. have the advantage of building a strong case to cover defective products by using previous discovery items that Wakanda co. had produced in prior cases. ${ }^{166}$ The defendant's lawyers would have the advantage of cumulative knowledge of facts derived from prior discovery items produced by the defendant. These would tilt the power scale in the defendant's favor and give the defendant more advantage in the settlement agreement with Obaham. This vicious circle would repeat itself over and over in many other cases for decades.

\footnotetext{
${ }^{160}$ Sunshine in Litigation Act of 2009: Hearing on H.R. 1508 Before the Subcomm. on Commercial \& Admin. Law Comm. on the Judiciary, 111th Cong. 1 (2009) (testimony of Leslie A. Bailey, Staff Att'y, Public Justice) ("In short, through protective orders, secret settlements, and sealed court records, the public courts are being used by private parties to hide smoking-gun evidence of wrongdoing.").

${ }^{161}$ Fiss supra, note 14 at 1076-1078 (1984), (arguing that power imbalance is a negative denominator in settlement regime and big companies use it to their advantage at the expense of poor litigants. ) See also Francis H. Hare, Jr. Et Al., Confidentiality Orders 21 (John Wiley \& Sons, Inc. 1988) (“Corporate defendants have achieved efficiency by using economies of scale, regional or national coordination, and cost spreading among related cases.").

${ }^{162}$ Comes v. Microsoft Corp., 775 N.W.2d 302, 310-11 (lowa 2009) ("When we add to the mix the time, money, and effort expended by counsel and support staff for the lowa plaintiffs in organizing and analyzing the information after Microsoft produced it, the staggering cost of repeating the process in the Canadian litigation comes even more sharply into focus.").

${ }^{163}$ Patterson v. Ford Motor Co., 85 F.R.D. 152, 153-54 (W.D. Tex. 1980) (acknowledging that collaboration between plaintiffs' attorney advances Rule 1 objective).

${ }^{164}$ Garcia supra note 158 at 343,348 (concluding that the trial court abused its discretion by refusing shared discovery in similar litigation).

165 This expression here means to embark on a discovery of information discovered in prior litigation.

${ }^{166}$ See Francis supra note 161 at 21 ("Corporate defendants have achieved efficiency by using economies of scale, regional or national coordination, and cost spreading among related cases.").
} 
Preventing the use of discovery information in subsequent litigations, and protective orders that encourage deference to the issuing court disarm plaintiffs and equip defendants especially in product liability cases in two ways. First, as noted earlier, it increases the cost and resource of the plaintiffs to bring claims against the defendants while it decreases the defendant's expense and efforts since the latter would rely on previous discovery items to build a strong case or initiate a self-serving settlement agreement. Thus, while cost considerations tilt the bargainingpower scale in favor of the malfeasant defendants it reduces the number of litigations against the defendant-company. ${ }^{167}$

Second, encouraging absolute deference would allow defendants, especially big corporations to exploit the financial weaknesses of litigants to gain more advantage and conceal more harm. ${ }^{168}$ Trial courts that insist on clauses that enable the non-rendering court to subsequently modify a protective order would create mechanisms for weaker litigants to compare discovery items with other litigants which may reveal discovery misconduct such as perjury in deposition and so on.

\section{Approaches to Protective-Order Modification in Non-rendering Courts}

Certainly, parties and nonparties may move courts to issue discovery orders in cases pending before them, and "these courts have not shied away" from such requests even though it may vacate, modify or lift protective orders issued by another court if, under the situations, such a decision was regarded as justified. ${ }^{169}$ Therefore, while courts have deferred or refused to defer to the issuing court to modify prior protective orders in separate cases, their decisions have been based on specific, distinguishable and varying situations. ${ }^{170}$

\section{Textual Approach}

Non-rendering courts faced with requests to modify the protective order of another court commonly evaluate the nature of the prior order and the relevant role of the prior court. Typically, parties in products liability and commercial cases after entering secrecy agreements ${ }^{171}$ on the modalities for the management of sensitive items obtained through the discovery process, they present these agreements to the court for its imprimatur. ${ }^{172}$ Courts frequently signed these agreements without deliberations on the weight of confidentiality attributed to this the so-called sensitive items or their negative implications on subsequent litigants. ${ }^{173}$

${ }^{167}$ Id. 69-70 made a similar argument but in the context of shared discovery.

168 Id.

${ }^{169}$ See Tucker case supra, note 3 at 495, 499-500; Barrella supra note 16.

${ }^{170} \mathrm{Id}$.

${ }^{171}$ See generally Manual For Complex Litigation $§ 21.432$ at p. 67-72 (3d ed.1995).

172 Tucker case supra note 3 at 495, 499 "[t]here is less need for deference and comity when the order involved is an agreement by counsel approved, almost as a ministerial act, by the court, than an action directed by the court after a full consideration of the merits of a fully briefed dispute."

173 Id. ("As such, they do not reflect any conclusion by the court regarding the appropriateness of designating particular documents as confidential, according to Fed.R.Civ.P. 26(c)(7). ") 
Settlement agreements of this nature are often one-sided, placing most of the burden on the party receiving the protected items. ${ }^{174}$ All of these as well as the fact that the stipulated orders do not represent the true will of the issuing court and the standards provided under Fed.R.Civ.P. 26(c)(7) makes the role of the issuing court "after the fact." ${ }^{175}$ Considering the above analysis, a non-rendering court faced with a request for protective-order modification may find less need for deference to the issuing court ${ }^{176}$

\section{Source-of-Document Approach}

A court has established that non-rendering courts when faced with the request to modify the protective order of another court, should consider "the identity of the party from whom discovery is requested." The Tucker court found less need for deference and comity where the party from whom the discovery was requested was the source of the confidential items in the prior litigation in the issuing court. Thus, the court may require deference and comity where the party from whom discovery is demanded in the subsequent litigation was not the producing party in the prior case. ${ }^{177}$ Mandating the production of discovery materials requested directly from a litigant who was the source of the items in the prior litigation does not in any way emasculate the weight or potential of the protective order issued by the previous court. ${ }^{178}$ Unless the court adopts this approach the party insisting on deference "might forever be insulated from producing discovery" in the subsequent litigations, by "having once produced it in a protected fashion" in the previous case. ${ }^{179}$

In Carter-Wallace, Inc. v. Hartz Mountain Industries, ${ }^{180}$ Carter-Wallace sought access to deposition transcripts produced by Hartz in prior settled litigation. Hartz objection was on the basis that a prior protective order protected the discovery materials, restraining disclosure and use outside the previous litigation.

The Carter-Wallace court held that Hartz, the defendant in the prior and present litigation, could not refuse disclosure because of the prior protective order since it was not the "receiving

${ }^{174}$ Id. ("Further, as in this case, such agreements frequently are one-sided, imposing all the obligations on the party seeking discovery, and affording all the protections to the party that initially resisted it.") But see. Public Citizen supra, note 1 at 775, 782 ("The Supreme Court established long ago that even an injunction entered by consent of the parties - and this protective order was entered over the objections of the plaintiffs - is always modifiable.").

$175 \mathrm{Id}$. See also Broyhill supra, note 5 at 527, 530 ("This is quite a different situation than that presented when a discovery dispute is raised before a court and, after a full hearing, it issues an order reflecting its deliberative process and decision.").

${ }^{176}$ But see "Martindell supra, note 26 at_291, 296-97 (where the court found "a strong presumption against access" to confidential items where there is reasonable reliance on an initially granted protective order subject to a showing of extraordinary circumstances). See also Freund v. Weinstein, CV 2008-1469 (FB) (E.D.N.Y. Apr. 23, 2013).

177 But See Tucker noting that ("In this regard, it should be noted that discovery is sought in this case not from the party against whom the obligations of the Texas Order apply, the Hernandezes, but instead from the source of those documents, Ohtsu")

${ }^{178}$ Carter-Wallace supra, note 23.

$179 \mathrm{Id}$.

18092 F.R.D. 67 (S.D.N.Y. 1981), 
party" in the prior case. The prior order placed non-disclosure obligations on the receiving party, not the producing party. ${ }^{181}$ Therefore, compelling the production of the information directly from the party who produced them in the previous litigation did not in any way deplete the efficiency of the prior order and the jurisdiction of the issuing court.

Non-rendering courts have declined motions to modify the orders of another court where the party from whom production is sought in the subsequent case was the receiving party in the prior litigation. ${ }^{182}$ Thus, the non-rendering court will defer to the issuing court where the party from whom discovery is sought is not the source of the materials in the prior case and nothing is suggesting that the source of the materials will perpetually be insulated from subsequent cases. ${ }^{183}$ Also, the party against whom discovery is sought must have the capacity to produce the material in question. Courts have declined discovery even where it is from the source when the demand is not narrowly tailored. ${ }^{184}$

\section{Litigation Cost}

Tucker court established that non-rendering court should consider whether the litigation in which the prior "protective order was issued is still pending, if not, the burden and expense to the [requesting party] if they are required to file a new action in the [the issuing] court simply to seek a modification of the Order issued there." 185 Where the initial court has settled litigation, and there is no pending action before it, deference to that court for modification of its prior order only for the sake of a collateral lawsuit, especially by litigants who were not parties to the previous order, does not only place an "unfair burden" on it but also inflicts "substantial hardship" on collateral litigants or the party requesting discovery. ${ }^{186}$

There is even more pressing presumption against deference when it would only amount to moving the issuing court, for the first time, to deliberate on a challenged discovery order which it never initially contemplated on the merits and the result of which will be significant merely to collateral litigation. ${ }^{187}$ Equally, considering the purport of Fed.R.Civ.P. 26(b)(2), to permit the requesting party in the subsequent litigation to suffer the expenditure of moving the issuing court to modify its initial protective order would amount to the imposition of greater burden and cost than if the present court determines the issue. ${ }^{188}$ This creates more incentives for the non-rendering court to have less need for deference. ${ }^{189}$ Tucker seems to create a rule that also

${ }^{181}$ Carter-Wallace supra note 23 ("the discovery request was explicitly directed at Hartz, the party that originally controlled the evidence and was the source of the information." Thus, Hartz was not bound by an order which by its terms prohibits disclosure only by "the receiving party.")

182 Id.

183 Barrella supra note 16.

${ }^{184}$ Id. (While distinguishing the instant case, District Judge Arthur Spatt held that "[t]he Carter-Wallace Court ordered the defendant to produce only the transcripts of its employees' depositions, not the transcript of every single deposition conducted in that case as well as every single document,")

185 Tucker case supra note 3.

186 Id.

187 Id.

188 Id.

189 Holland v. Summit Technology, Inc., CIVIL ACTION NO. 00-2313 SECTION "C" (3) (E.D. La. Sep. 21, 2001) 
has an inverse form, that is, where the underlying litigation is pending, the non-rendering court should as a matter of comity defer to the issuing court and parties seeking modification would have to move the issuing court provided it is cost-effective for the requesting party. ${ }^{190}$

\section{Variation of Existing Rights and Obligations}

One court reasoned that the non-rendering court dealing with the prior protective order of another court should do so in such a way that would not radically vary the terms of the initial order. One effective way by which this is done is to impose on the requesting and receiving parties the degree of obligations and protections respectively imposed on them in the initial litigation. ${ }^{191}$

Emphatically, production of discovery materials in subsequent litigation, which comes under the span of the order initially issued by the previous court, will be limited to the same precincts as the prior order. As regards any items requested concerning the initial litigation, which does not come under the scope of the previous order, their discovery shall be subject to the confidentiality order put in place by the current court. ${ }^{192}$

\section{The Doctrine of Allocation of Authority}

There is the reasoning that deference entails that instead of giving respect to the order or decisions of another entity, one entity might allocate authority to another to make enforceable orders or decisions. ${ }^{193}$ In this sense, the assigned authority does not need to be absolute; its exercise might be restricted to certain exceptions or principles. ${ }^{194}$ For example, the decision in Stavro v. Upjohn $\mathrm{Co}^{195}$ seems to suggest this point. The US Court of Appeal argued that under the provisions of the Act ${ }^{196}$ "the powers of a district judge include the power to modify a protective order." 197 Thus, the act of transfer from the original court to the transferee court is a form of allocation of authority to modify or even vacate a protective order issued by the transferor court "when circumstances so dictate". What this position seems to suggest is that deference as a matter of allocation of authority entails that the transferor court has assigned its authority to the transferee court. Since the transferee court is already acting as the transferor

\footnotetext{
190 Tucker case supra note 3.

191 Id.

192 Dart Indus., Inc. v. Liquid Nitrogen Processing Corp. of California, 50 F.R.D. 286, 291-92 (D.Del. 1970) (limiting "production of documents to those not covered by any protective order of the Illinois district court in a prior lawsuit.").

193 Id.

194 Id. at 1-2(stating that "such authority need not be absolute: its exercise might be subject to limitations...").

${ }^{195} 664$ F.2d 114 (6th Cir. 1981).

19628 U.S.C. $\S 1407$.

197 Id. (citing American Telephone and Telegraph Co. v. Grady, 594 F.2d 594, 596 (7th Cir. 1978) cert. denied, 440 U.S. 971, 99 S.Ct. 1533, 59 L.Ed.2d 787 (1979). See also Wilk v. American Medical Association, 635 F.2d 1295, 1299 (7th Cir. 1980)
} 
court, which could not defer to itself, there is no need for deference. ${ }^{198}$ The court held that the practicality of this case requires the transferee judge to do what the occasion demands to harmonize the case and thus, the modification is not "offensive to the transferor court or breaches notions of comity" rather it enhances the allocation of power theory of deference.

Thus, construing deference as a sphere of authority has been criticized because such a notion creates the presumption that deference rule is absolutes. ${ }^{199}$ In this context, since the rule of deference is not absolute ${ }^{200}$, insisting on 'spheres of authority' insinuates that the decision to modify the protective order ought to be allocated to the transferor court on 'an absolute rather than a relative basis. ${ }^{201}$

A theory of deference that requires the transferee court to refer a protective order to the transferor court on an absolute basis is an invitation to formalism, ${ }^{202}$ which does not just inhibit the transferee court's effective determination of the issues before it but also corrode its discretion and capacity to act as a district judge under the Act.

\section{PROPOSAL FOR PROTECTIVE-ORDERS MODIFICATION IN NON-RENDERING COURTS}

Hostility toward non-rendering courts' modification of prior protective order is contrary to both the substance of the Federal Rules Civil Procedure, Duke Conference and the objectives of the proposed civil amendments. ${ }^{203}$ This part examines principles for the treatment of protective orders in non-rendering courts. This part argues for the abolition of ouster clauses in protective others and more use of modification-enabling clauses that empower the subsequent court to modify prior order for the limited purpose of ensuring efficient discovery in related litigations. The need for deference would not have arisen had the issuing court in the exercise of its discretion at the point of entering the protective order insists on modification-friendly clauses that enable the non-rendering court to modify the former's protective order. As a matter of comity, one court should not make an order that will interfere with the subsequent authority of another court.

\footnotetext{
${ }^{198}$ Deference is relational: one authority showing respect to another authority.

${ }^{199}$ Daly supra, note 93 ("establishing spheres of authority suggests that decisions ought to be assigned to [certain bodies] on an absolute rather than a relative basis.")

${ }^{200}$ Bobala v. Bobala, 68 Ohio App. 63 (Ohio Ct. App. 1940) (stating that principles of deference and comity are not obligations.).

${ }^{201}$ Daly supra, note 93.

202 David Dyzenhaus, Constituting the Rule of Law: Fundamental Values in Administrative Law (2002) 27 Queens $\sqcup$ 445, 450 (stating that "[f]ormalism is formal in that it requires judges to operate with categories and distinctions that determine results without the judges having to deploy the substantive arguments that underpin the categories and distinctions. Since those categories and distinctions must take on a life of their own to operate in this detached way, they are capable of determining results that contradict the very arguments for these categories and distinctions."

${ }^{203}$ Advisory Comm. On Civil Rules, Report To The Standing Committee 65-66 (May 2, 2014) ("A principal conclusion of the Duke conference was that discovery in civil litigation would more often achieve the goal of Rule 1-the just, speedy, and inexpensive determination of every action-through an increased emphasis on proportionality.").
} 


\section{A. Modification-enabling Clauses Versus Subsequent Modification}

In very many ways, the inclusion of modification-enabling clauses in protective orders to empower non-rendering courts should be favoured over subsequent modification and deference to the issuing court. This approach has its foundation in Rule 26(c)'s good cause standard and functions within the well-defined perimeter of the trial court's broad discretion over protective orders. ${ }^{204}$ Evidence of good cause will not validate protective orders that forbid subsequent courts from modifying them in related litigations. ${ }^{205}$ The content and scope of the protective order should be restricted to what is necessary to protect the producing party from injury instead of crafting the order in a way that ousts the authority of subsequent courts. ${ }^{206}$

The frequent injury contemplated by parties seeking protective order is the economic or proprietary harm resulting from disclosure to competitors. ${ }^{207}$ Protective orders that do not oust non-rendering courts can still curb this harm through three drafting mechanisms. First, the orders should have a clause that expressly restrains the transfer of discovery materials to competitors of the producing party and sanction noncompliance as contempt. Second, the terms of the order could be narrowly fashioned in such a way as to permit their use in nonrendering courts solely in related litigations with strong factual connections to the action in which the order was issued. Third, the provisions of the protective order should be narrowly drafted to allow modification by an equivalent court of competent jurisdiction when requested to modify the order subject to the non-variation of existing rights and obligations of the parties in the prior order. ${ }^{208}$ Removing competitors from those with access rights diminishes the most probable (and frequently only) source of injury resulting from exposure of discovery items.

Numerous courts have continued to enter protective orders with outer clauses, even where there is a likelihood of multi-jurisdictional lawsuits. ${ }^{209}$ The reasons for this may vary from court to court but most courts are induced by the incentives for settlements for now without consideration of future litigants that may need the discovery materials. ${ }^{210}$ This approach does not only contradicts the provisions of Rule 26(c)'s requirement that the grant of a protective order be established by showing of good cause, but also corrode Rule-1 efficiency in subsequent courts by inflicting unfair burdens on legitimate litigants and the system with no corresponding entitlements.

Entering protective order without ouster provisions are more effective than subsequent request to intervene and modify. First, abolishing the use of ouster provisions diminishes

\footnotetext{
${ }^{204}$ See FED. R. CIV. P. 26(c) (“The court may, for good cause, issue an order to protect a party or person from annoyance, embarrassment, oppression, or undue burden or expense.")

205 8A WRIGHT ET AL. supra, note 34 at $\S 2035$ (reasoning that specific evidence of injury must support entry of a party-restraining protective order).

${ }^{206}$ Provisions like the one in Barrella case should be avoided -see note 16.

207 See Miller supra note 17 at 483.

${ }^{208}$ See Tucker case supra note 3 (stating that subsequent court should give effect to the existing obligations and rights of parties in the prior order.).

${ }^{209}$ Stavro case supra note 197.

${ }^{210}$ See generally Fiss supra note 14.
} 
litigation concerning discovery items. ${ }^{211}$ When properly crafted, protective orders that enable non-rendering courts to modify them diminish discovery controversies by permitting subsequent courts to discovery items without the stress of deference to the issuing court for intervention and modification. By comparison, every subsequent litigant who intends to use existing discovery items in prior litigation protected by ouster clauses must have to intervene and request the modification of the prior order. ${ }^{212}$ This procedural bottleneck not only frustrates litigants from making practical and efficient use of existing discovery information but also results in unnecessary discovery litigations. ${ }^{213}$

One may speculate that advocates of this pattern of thought believe that cunning litigants in jurisdictions with restricted discovery could locate related litigations with lax ouster clauses in a jurisdiction with liberal discovery framework. ${ }^{214}$ Whether or not a protective order lacks ouster clause it does not cause injury to the producing party in any sense contemplated by Rule 26(c). When the prior discovery items are used in subsequent litigations the producing party has previously spent resources to finalize the discovery in the prior court. ${ }^{215}$ The collateral litigants obtaining access is responsible for footing the cost for a duplicate of the items. ${ }^{216}$ Also, the litigants in the subsequent action profiting from the discovery items will virtually consent to the terms of the initial order such as the use of the items only for the collateral litigation. The requesting and producing parties would save time and conserve resources and efforts. ${ }^{217}$ This will also advance the efficiency of the litigation system.

Nevertheless, protected discovery does not avert liability; it is a mechanism to search for truth without injury to the producing party. ${ }^{218}$ Thus, if the use of discovery items in related litigations turn out to be relevant and admissible, litigation in the non-rendering court would be efficient. ${ }^{219}$

Equipped with more evidence from prior discovery, lawyers will be less prone to embarking on discovery litigation in the non-rendering court, saving resources for that issuing judge who would not have to deliberate on the request for modification ${ }^{220}$. And the availability of more materials rather than scarce information is commonly helpful in searching for the truth.

One identifiable fear, although unlikely to happen frequently, is that lawyers embarking on nationwide litigations might exploit jurisdictions with uncommonly liberal discovery criterion

\footnotetext{
211 The debate over deference to the issuing court has to lead to many litigations. See notes 1-7.

212 Id.

213 Id.

${ }^{214}$ Cordis Corp. v. O’Shea, 988 So. 2d 1163, 1167 (Fla. Dist. Ct. App. 2008) (“Allowing this degree of sharing of confidential information may provide a mechanism for attorneys in states with narrower discovery laws to evade their state law discovery limitations ....").

${ }^{215}$ Ward v. Ford Motor Co., 93 F.R.D. 579, 580 (D. Colo. 1982)

${ }^{216}$ Raymond Handling Concepts Corp. v. Super. Ct., 45 Cal. Rptr. 2d

885, 886 (Cal. Ct. App. 1995)

217 See Tucker case supra note 3 and Broyhill supra note 5.

218 Hickman v. Taylor, 329 U.S. 495, 507-08 (1947).

${ }^{219}$ See Garcia v. Peeples, 734 S.W.2d 343, 347 (Tex. 1987).

220 See Tucker case supra note 3.
} 
and establish a discovery factory for other litigations across the nation. ${ }^{221}$ Putatively, the lawyers could file a case to get lenient discovery orders, obtain a modification-friendly protective order and subsequently utilize the jurisdiction to supply litigations across the country, irrespective of the merit of the claim in the non-rendering court. The possibility of this even occurring is slim, and in the event of its occurrence, the issuing or non-rendering courts would have the discretion to modify the protective order to close the discovery factory. While it is inappropriate for lawyers to embark on such forms of discovery, the mere apparition of such misapplication should not form the basis for ousting the jurisdiction of non-rendering courts in favor of deference to the issuing court for modification of its order, especially when non-rendering courts have adequate resources to address abuses that may occur.

Besides the explicit efficiencies derived from discouraging the use of ouster clauses in protective orders, modification-friendly provisions similarly create some implicit, systemic advantages. Modification-friendly clauses enhance party cooperation and efficiency by circumventing reliance concerns and adequately structuring what parties anticipate at the point of entering the protective orders. ${ }^{222}$

Courts facing motions for modification of protective orders commonly grapple with issues about reliance. ${ }^{223}$ Frequently courts are reluctant to modify initial orders to permit use in collateral litigations because parties originally produced items in reliance on secrecy orders. ${ }^{224}$ The basis for this reluctance is that parties produced the materials with the expectation that they would be used for the limited purpose of that specific litigation. By frustrating the party's secrecy expectations, the speculation is that parties feel unlikely to produce materials under the protected discovery in the future, thereby diminishing efficiency and increasing other concerns for the discovery system at large. ${ }^{225}$

Irrespective of the actual degree and consequences of reliance concern, incorporating collateral-jurisdiction-enabling clauses into protective orders diminishes fears about reliance completely in many circumstances. A well-drafted protective order with clauses that enables collateral jurisdiction, all parties become aware from the beginning that related litigants in subsequent courts under similar protection might use them discovery items. The boosted assurance that they enjoy the same level of protection in other courts may even, on its own, enhance parties' willing to cooperate at the discovery in the issuing court.

In numerous litigations, especially products-liability and mass tort litigations, subsequent motions for modification by similar litigants are reasonably anticipated. Courts should properly align party expectations by entering collateral-jurisdiction-enabling protective orders that deal with these practicalities from the beginning.

\section{B. Protective-Order Modification Standards For Non-rendering Courts}

\footnotetext{
${ }^{221}$ See Cordis Corp. v. O’Shea, 988 So. 2d 1163, 1167 (Fla. Dist. Ct. App. 2008).

${ }^{222}$ C.f Martindell case supra, note 26.

$223 \mathrm{Id}$.

$224 \mathrm{Id}$.

225 Id.
} 
Many earlier courts to address protective-order modification in non-rendering courts adopted varying standard. However, Tucker court harmonized these variations into four principles $^{226}$, The Tucker principles foster to Rule 26(b)(2) considerations and gives effect to the Duke conference and the objectives of the intended civil rules amendment. ${ }^{227}$

Before this decision, some non-rendering courts had taken a separate view by setting an extremely high stake to collateral litigants request to modify prior protective order of another court. The basic reason for this stringent approach is the purported injury that may occur to parties who produced materials at the discovery in reliance on the prior protective order. These reasons can be faulted on many realities.

First, numerous protective orders are stipulated umbrella orders that were merely endorsed by the issuing court. ${ }^{228}$ Thus, by their nature, they are private contracts and permits parties to the litigation to contest the secrecy of the documents. It is difficult to reason how litigants respect this category of orders and rely on its secrecy. A party producing presumably secreted materials under an umbrella stipulated order is taking a risk; there is no presumption of reliance on future confidentiality.

Second, issuing courts frequently modify protective order to allow third party access to use discovery items in product liability litigations. ${ }^{229}$ To that end, parties are aware that modification is constant in the litigation system; any reliance on presumed rigidity of protective order is unreasonable $a b$ initio.

Assuming a party has a reliance on a prior protective order for secrecy, the injury arising from a modification that permits access to discovery items in related actions would only be insignificant or may not exist in most circumstances. After all, there are only two possible instances by which injury may occur from subsequent modification of protective order to permit the use of discovery items in related litigations, and none of these validates strenuous modification criteria. First, a litigant producing incriminating discovery items from the issuing court may be held liable in the non-rendering court for actual wrongdoing that the items unveil. While this may not favor the producing party, non-rendering courts should not decline modification request on comity considerations because it would make the producing parties escape liability in subsequent litigations. While parties by some flux may use the rules to escape liability by hiding under the cloak of the protective order, insulating them from (future) liability

\footnotetext{
${ }^{226}$ First, the court evaluated the nature of the prior protective order and the relevant role of the prior court. Second, the Tucker court contemplated "the identity of the party from whom discovery is requested." Third, the non-rendering court has also considered whether the litigation in which the prior "protective order was issued is still pending, if not, the burden and expense to the plaintiffs if they are required to file a new action in the [the issuing] court simply to seek a modification of the Order issued there." Lastly, the subsequent court should deal with prior order in the manner that allows only the incorporation of terms in the current order that will foster the protections initially ordered by the prior court.

${ }^{227}$ See Commentary to 1993 changes to Fed.R.Civ.P. 26(b)(2), 146 F.R.D. 401, 613 (1993).

${ }^{228}$ See notes 1-7.

229 Id.
} 
by secreting discovery items against use in subsequent litigations is not a proper use of discovery contemplated within the civil rules and current amendment trends. ${ }^{230}$

Numerous courts have supported the idea that the use of discovery items in subsequent court can reveal discovery misconduct and courts can enforce liability against defendants for altering discovery responses among diverse litigations. ${ }^{231}$ To the extent that the producing party in the issuing court relies on a protective order to shield him/her from disclosure that would make him/her liable in subsequent litigations, such reliance has no foundation in Rule 26 provisions. $^{232}$

Another injury that Rule 26 might consider is that the heightened danger of dissemination would likely diminish the competitive value of discovery items. ${ }^{233}$ The subsequent modification of a protective order whether by the issuing or non-rendering court broadens the parties with access. Every modification makes it insignificantly feasible that a breach might occur and someone might reveal confidential items to the public. ${ }^{234}$ The feasibility of disclosure is even more heightened in this age of advance digital technology, which could aid one receiver to disseminate discovery items to the whole world within seconds.

However, the practice has demonstrated that the possibility of a significant breach of protective-order terms is relatively scarce. ${ }^{235}$ The relatively scarce instances of protective-order breach possibly result from grave consequences imposed on lawyers who breach these orders. ${ }^{236}$ One likely punishment is contempt, which is the possible use of a lawyer's breach as proof in subsequent courts to preclude that attorney from access to discovery in future litigations. ${ }^{237}$ Although it is a notably less formal sanction but constitutes significant deterrence to prevent the breach of protective orders.

When non-rendering courts weigh the dangers of modifying prior protective orders, they should concentrate on the actual or reasonably foreseeable injury, not speculative risks. ${ }^{238}$ Protective-order breaches are scarce, but illegal dissemination to competitors of a producing party as a consequence of modifying protective order is almost nonexistent.

Martindell court stated that a party moving a non-rendering court to modify a protective order to permit the use of discovery items in criminal litigation must pass the "extraordinary circumstances" test. It is not difficult to see the policy underpinning this decision: many witnesses waived their Fifth Amendment right and testified at a deposition in reliance on the

\footnotetext{
${ }^{230}$ Tucker court supra note 3 (stating that something is unsettling about insulating the producing party from cooperation in subsequent litigations, by having once produced it in a protected fashion in the prior case.).

${ }^{231}$ See In re Abbott Labs. Sec. Litig., No. 92 C 3869, 1993 WL 616693, at*4 (N.D. III. Nov. 15, 1993).

${ }^{232}$ But see Martindell supra note 26 at 291, 295-96.

${ }^{233}$ Richard P. Campbell, The Protective Order in Products Liability Litigation: Safeguard or Misnomer?, 31 B.C. L. REV. 824 (1990)

${ }^{234} \mathrm{Id}$.

235 McDonald v. Cooper Tire \& Rubber Co., 186 F. App'x 930, 932 (11th Cir. 2006).

${ }^{236}$ Richard L. Marcus, A Modest Proposal: Recognizing (at Last) that the Federal Rules Do Not Declare that Discovery Is Presumptively Public, 81 CHI.-KENT L. REV. 331, 348 (2006).

${ }^{237}$ FED. R. CIV. P. 26(g)(3) and 37 justify the court's authority to penalize the party's lawyer for violating certification standards for discovery.

${ }^{238}$ But see Martindell case supra, note 26.
} 
secrecy of the protective order. The court's concern, quite correctly, was that permitting a nonrendering court to modify the prior protective order would scare future parties in related instances from maximum cooperation in discovery system, especially when the litigation has some spices of criminal culpability. On the scale of the Martindell court, the need for deference tilts against the party seeking modification in a non-rendering court.

However, Martindell creates three factors that require some degree of analysis. First, the rationale that modification by a non-rendering court would deter future parties from reliance on protective order and the discovery system is at best a speculation. Issuing and non-rendering courts have long modified protective orders and there are no concrete proofs to establish that litigants have been deterred from reliance on them. ${ }^{239}$ Today, a protective order is a commonplace device in America litigation; parties have not stopped using it even in the face of subsequent modification. ${ }^{240}$ It is also speculative because every future witness cannot dig into the past of what has occurred in previous protective-order modification to form an opinion for future noncooperation.

Second, the nature of the power imbalance in favor of the party seeking access must have swayed the court to establish the extraordinary circumstances test. Due to the enormous investigatory powers available to the government, it can always get the information it requires without unsettling private party's protective-order arrangements. ${ }^{241}$ Thus, the outcome may not be the same in the context of a private party legitimately seeking access to prior discovery to aid efficient proceeding in subsequent litigation.

Third, the admixture of the civil and criminal contents of the case might have also swayed the court to the direction it took; such generalizations could not have been validated in regular civil situations. There is no proof that parties in regular civil litigation would refrain from subsequent discovery because of the possibility of subsequent modification by a non-rendering court.

The Tucker court rightly supported the presumption against deference to the issuing court for a protective-order modification to permit a collateral party access to discovery items without substantially prejudicing the interest of the party insisting on deference to the issuing court to modify the order. ${ }^{242}$ This modification-friendly posture weighs equivalent interests as those in Martindell but gives them spectacular significance.

Instead of speculating the potential injury to parties' reliance, the Tucker test requires a party insisting on deference to the issuing court for protective-order modification to show actual injury resulting from the reliance and the prejudice arising from non-deference. Similarly, while Tucker court gave heavyweight to the prior order of the issuing court, it fosters the advantages of a non-rendering-court modification of prior protective order. Proof based approach to deference reasonably balances reliance considerations and the need for efficiency in

\footnotetext{
239 See notes 1-7.

240 Marcus supra note 11 .

241 Martindell supra, note 26 at 291, 296 ("[T]he Government as investigator has awesome powers which render unnecessary its exploitation of the fruits of private litigation.") citing GAF Corporation v. Eastman Kodak Company, 415 F.Supp. 129, 132 (S.D.N.Y. 1976).

${ }^{242}$ See Tucker case supra, note 3.
} 
subsequent litigation without having to waste time and resources in the voyage to the issuing court for modification or the need for discovery.

A modification-friendly regime fosters the ongoing proposal for civil rules amendment.

When a non-rendering judge modifies a prior protective order to give collateral parties before his access to discovery items covered by the order of another court, it only aids the discovery process in the non-rendering court. This approach has its foundation in Rule-1 efficiency considerations.

Nothing is making a modification by an issuing court different from modification by a non-rendering court provided these courts use the common standards of modification especially the one espoused in the Tucker case. And where these standards vary, it is only because of the variation of judicial discretion, which has come to stay.

\section{CONCLUSION}

Numerous courts have long acknowledged the need for deference to the issuing court for modification of its protective orders, even though commentators have either ignored it or give it very insignificant attention. Courts remain unstable in their approach to this topic. Litigants and non-rendering courts suffer as a result. Advocating for modification-friendly clauses and the less use of ouster provisions in protective orders would empower non-rendering courts to easily modify protective orders in subsequent litigation without having to defer to the issuing court. This would be a positive step in the direction of ongoing civil procedural reform. Equally, modification makes both issuing and non-rendering courts efficient and effective in discovering the truth without an undue burden in litigants and courts. The modification will prevent shielding parties who intend to remain insulated from liability resulting from their wrongdoing. Issuing courts functioning within the parameters of Rule 26(c) and other enabling statutes and rules, should exercise their discretionary power to actualize these advantages. 